\title{
Optimization of Electrocoagulation Process for the Removal of Binary Dye Mixtures Using Response Surface Methodology and Estimation of Operating Cost
}

\author{
Abdul Rauf Shah, Hajira Tahir, Hafiz Muhammad Kifayat Ullah, Asma Adnan \\ Department of Chemistry, University of Karachi, Karachi, Pakistan \\ Email: hajirat@uok.edu.pk
}

How to cite this paper: Shah, A.R., Tahir, H., Ullah, H.M.K. and Adnan, A. (2017) Optimization of Electrocoagulation Process for the Removal of Binary Dye Mixtures Using Response Surface Methodology and Estimation of Operating Cost. Open Journal of Applied Sciences, 7, 458-484. https://doi.org/10.4236/ojapps.2017.79034

Received: July 18, 2017

Accepted: September 25, 2017

Published: September 28, 2017

Copyright $\odot 2017$ by authors and Scientific Research Publishing Inc. This work is licensed under the Creative Commons Attribution International License (CC BY 4.0).

http://creativecommons.org/licenses/by/4.0/

\begin{abstract}
The study was useful for the treatment of Reactive red 223 (R223) and Coomassie brilliant blue R250 (CBBR250) binary dye system by electrocoagulation process (EC). Moreover, the $\mathrm{Al}$ and Fe electrode were used as an anode and cathode, respectively. The response surface methodology (RSM) was adopted by utilizing central composite design to plan the experimental runs. The EC process was preceded under the effect of operating parameters including $\mathrm{pH}$, $\mathrm{NaCl}$, voltage and electrolysis time. The \% color and COD removals were examined as response variables. The removal efficiency of RR223 and CBBR250 dye at optimum values was $89 \%$ and $94 \%$ and COD removal was $100 \%$. The kinetic study was performed to determine the rate and rate constant. First and second order kinetic models were studied to figure out the exact mechanism of the dye removal using EC process. The estimated cost of the experimental design about $4.486 \mathrm{US} \$ / \mathrm{dm}^{3}$ was also determined. This study showed that EC process is an economical way for the treatment of waste water.
\end{abstract}

\section{Keywords}

Electrocaogulation, Central Composite Design, Kinetic Study, FTIR, Color, COD

\section{Introduction}

The water bodies are being contaminated due to industrial and domestic discharges. To protect water reservoirs and living organism from life threatening diseases, various treatment methods were designed [1]. Dye is also considered as 
a major pollutant to pollute water. Additionally, they are of great concern owing to massive worldwide production of dye stuffs. There are over 100,000 commercially accessible dyes with an assessable annual production over $7 \times 10^{5}$ tons of dye-stuff [2]. These discharges from various industries have metals, salts, coloring substances, total phosphate, dissolved solids and total suspended solids (TSS) [3]. Conversely, it decreases the light penetration in water bodies to bioaquatic ecosystem and increases COD demand [4]. Moreover, they adversely affect on the concentration of dissolved gases in giant water bodies [5]. Textile effluent has carcinogenic compounds: textile discharge contains high color, $\mathrm{pH}$ ranges about (2 - 12), high organic and low biodegradability [6]. Biological treatment is not successful to treat textile waste due to toxicity for living organism; they cannot survive in such aqueous environment [7]. Electrocoagulation has several advantages over the other treatment process [8]. Moreover, in this method, metal hydroxide is generated that coagulates pollutants by charge neutralization, surface complexation and adsorption methods. Mostly, Fe and $\mathrm{Al}$ electrodes are utilized to produce metal hydroxides. They are effectively utilized for the treatment of industrial discharges from tannery [9], textile [10], bio-digester [11] etc. Moreover, the EC process involves several phenomena including discharge of gases, anodic dissolution, cathodic reduction like hydrogen gas evolution, coagulation, natural process migration, and adsorption. Simultaneous evolution of hydrogen gas within the electrodes promotes the flotation process [12]. The metallic sludge obtained by EC is compact compared with those engendered by chemical process. The sludge that is formed as a result of electrocoagulation process also removes dye from solution by adsorption process. The general metal anode oxidation reaction can be expressed as:

$$
\mathrm{M}_{(\mathrm{s})} \rightarrow \mathrm{M}_{(\mathrm{aq})}^{n+}+n \mathrm{e}^{-}
$$

Metal ions are able to neutralize the dissolved pollutants and additionally the electrolysis of water occurs at the cathode and anode respectively:

$$
\begin{aligned}
& 2 \mathrm{H}_{2} \mathrm{O}_{(\mathrm{l})} \rightarrow 4 \mathrm{H}_{(\mathrm{aq})}^{+}+\mathrm{O}_{2(\mathrm{~g})}+4 \mathrm{e}^{-} \\
& 2 \mathrm{H}_{2} \mathrm{O}_{(\mathrm{l})}+2 \mathrm{e}^{-} \rightarrow \mathrm{H}_{2(\mathrm{~g})}+2 \mathrm{OH}_{(\mathrm{aq})}^{-}
\end{aligned}
$$

Moreover, the anodic metal ions form hydroxide which depends on the $\mathrm{pH}$ of the EC system. The metal cations and hydroxide ions form various poly hydroxides of the metal ions, and sweep to coagulation.

$$
\mathrm{M}_{(\mathrm{aq})}^{n+}+n \mathrm{OH}_{(\mathrm{aq})}^{-} \rightarrow \mathrm{M}(\mathrm{OH})_{n(\mathrm{~s})}
$$

The consistency of the EC process is found on the basis of power consumption at industrial scale [13]. Moreover, they have advantage due to fast tendency of color removal and low cost compared to other classical treatment methods [14]. Consequently, the EC process was chosen to treat the dye effluent. The impact of operational variables including initial $\mathrm{pH},[\mathrm{NaCl}]$, Voltage and electrolysis time on color and COD was analyzed. Response surface methodology is a sta- 
tistical tool for the optimization of operational parameters for chemical process both at laboratory and industrial scale [15]. The present study focuses on impact of different operational parameters on color and COD removal from binary dye system. It can be employed for the treatment of waste water by designing a reactor at the waste stream by inserting only $\mathrm{Fe}, \mathrm{Al}$.

\section{Materials and Methods}

\subsection{Materials and Instruments}

The binary dye system was prepared by dissolving Reactive red 223 and Compassion brilliant blue R250 in deionized water. The structure of both of them is shown in Table 1 . The absorbance was measured by T80 UV/VIS Spectrometer. The digital DC power supply (Yaxun 1502DD; $15 \mathrm{~V}, 2 \mathrm{~A}$ ) was used to perform EC experiments. The $\mathrm{pH}$ was measured by (Portable $\mathrm{pH} / \mathrm{EC} / \mathrm{TDS} / \mathrm{Temperature}$ HANNA, H19811-5). A 78HW-1 serial constant-temperature magnetic pug mill stirrer was used to perform agitation of the solution during EC process. The glass EC reactor was designed having $500 \mathrm{~mL}$ capacity. The $\mathrm{Al}$ anode and $\mathrm{Fe}$ cathode were used to perform EC experiments. Whereas FTIR model NICOLET 67,000 was used to study the structural variation in dyes after the process.

\subsection{Electrocoagulation Setup}

The EC setup is given in Figure 1. The removal of binary dye system was carried out. The reactor consists of $\mathrm{Al}$ and Fe electrodes that are immersed in $500 \mathrm{ml}$ of dye content. The initial $\mathrm{pH}$ of system was measured by multiple (Portable pH/EC/TDS/Temperature HANNA, H19811-5). The electrodes are connected to a DC power supply. The distance between them were kept constant throughout the experiment. The samples were ejected at different time intervals and analyzed to note their absorbance. Moreover all the experimental runs were

Table 1. Reactive red 223 and Coomassie Brilliant Blue R250 dyes characteristics.

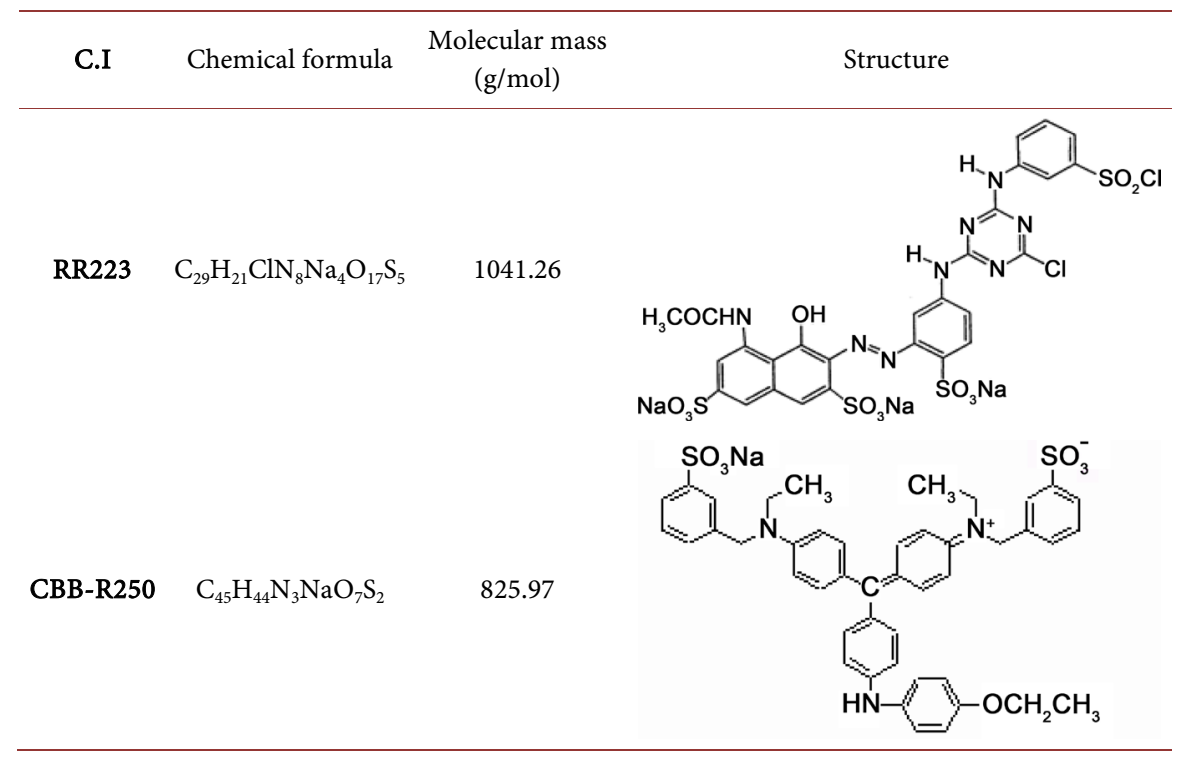




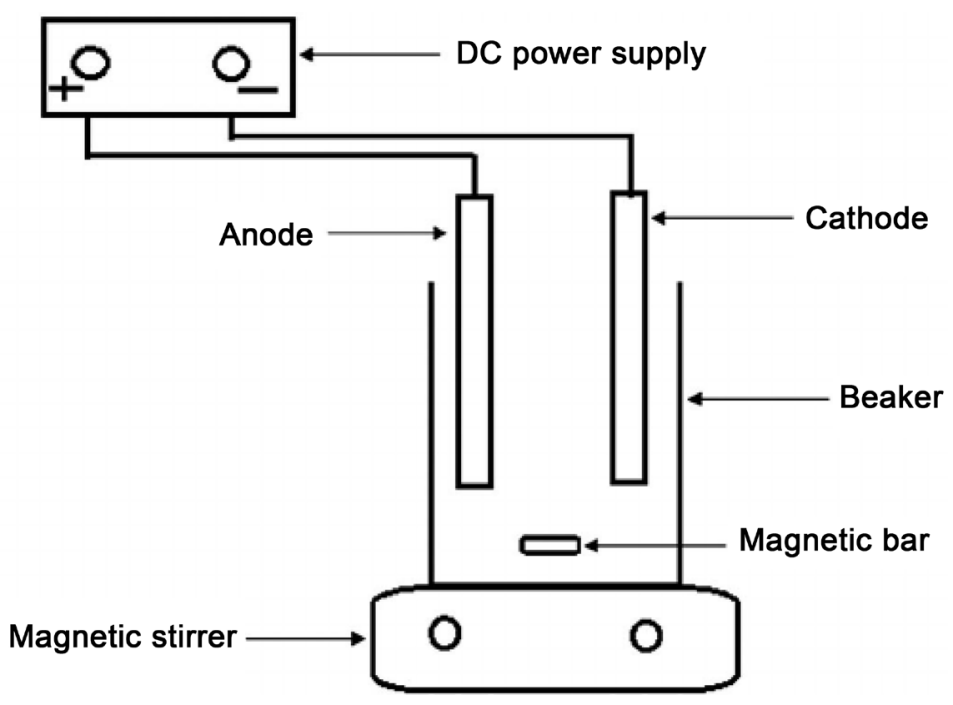

Figure 1. Schematic view of electrochemical batch reactor.

performed at constant temperature. After each run electrodes were washed by $\mathrm{H}_{2} \mathrm{SO}_{4}$ $(0.1 \mathrm{M})$ and $\mathrm{EC}$ reactor was cleaned by $\mathrm{HCl}(0.1 \mathrm{M})$. After each experimental run, samples were analyzed by determining its dye removal tendency and COD values.

\subsection{Determination of Removal Efficiencies}

The removal efficiencies of dyes were calculated as:

$$
\% \text { color removal efficiency }=\frac{X_{o}-X_{t}}{X_{o}} \times 100
$$

where $X_{o}$ - the [dye $]_{\text {initial }}$ and $X_{t}$-values [dye $]_{\text {final }}$ concentration in EC system after a certain EC time $(t)$.

\subsection{The COD Measurements}

The COD test is an indicator of organic component in waste water. They were pd by Standard Methods for Examination of Water and Wastewater (APHA, 1992) [16]. It is estimated as:

$$
\% \text { COD Removal }=\frac{[\mathrm{COD}]_{\text {initial }}-[\mathrm{COD}]_{\mathrm{t}}}{[\mathrm{COD}]_{\text {initial }}} \times 100
$$

where $[C O D]_{\text {initial }}$ and $[C O D]_{t}$ in EC process after a definite EC time period $(t)$.

\section{5. $\mathrm{pH}$, Conductance and TDS measurements}

The $\mathrm{pH}$, conductance and TDS were measured by (Portable $\mathrm{pH} / \mathrm{EC} / \mathrm{TDS} / \mathrm{Temperature}$ HANNA, H19811-5). The $\mathrm{pH}$ and conductivity were adjusted to a desirable value using $\mathrm{NaOH}, \mathrm{H}_{2} \mathrm{SO}_{4}$, and electrolyte $(\mathrm{NaCl})$ respectively.

\subsection{Calibration Curves}

The binary dye system of RR223 and CBB-R250 was run and their concentrations were determined by standard calibration curve method. 


\subsection{Central Composite Design for Dyes Removal}

The chemical process depends on different operational parameters they are optimized by RSM. Consequently, through this approach combine and interactive effect of factors are evaluated. Subsequently, the optimization of parameters is studied for \% color and COD removal. To check the significance of operation variables including $\mathrm{pH},[\mathrm{NaCl}]$, Voltage and electrolysis time has maintained. The CCD model with four factors at 5 levels is used to optimize the parameters for color and COD removal. Thirty (30) experimental runs are provided by software. A second-order polynomial model Equation (7) was applied to assess the correlations between the responses and also the freelance variables [17].

$$
Y=\beta_{0}+\sum_{i=1}^{4} \beta_{i} x_{i}+\sum_{i=1}^{4} \sum_{j=1}^{4} \beta_{i j} x_{i} x_{j}+\sum_{i=1}^{4} \beta_{i i} x_{i}^{2}
$$

where $Y$ represent the predicted function; $\beta_{0}$ is an intercept; $\beta_{p} \beta_{i p}$ and $\beta_{i j}$ are the linear coefficients, the quadratic coefficient, and the interaction coefficient, respectively; $X_{i}$ and $X_{j}$ represent the coded independent factors. The experimental runs determined by Minitab software 17 and their corresponding results are given in Table 2.

\subsection{Surface and Contour Plots}

Response surface plots provide a method to predict the decolorization efficiency of dyes. Moreover, the contours of the plots help to identify the type of interactions between these variables. The maximum predicted yield was obtained and it was indicated by the surface confined in the smallest curve of the contour diagram [18]. The respective plots are showing the variation in target responses owing to variation in levels of operational parameters.

\section{Result and Discussion}

\subsection{The Surface and Contour Plots of the Quadratic Model}

Figures 2-4 show the surface and contour plots obtained from the linear models built from the experimental results. Three (3D) dimensional and contour (2D) plots are drawn to check the effect of each variable on responses. The surface and contour plots of the quadratic model with two variables kept constant at their zero level and the other two varying within the experimental ranges. From the results, it was observed that in all the combined process variables showed the significant effect on the color and COD removal in electrocoagulation treatment process.

\subsection{Effect of $\mathrm{pH}$ on $\%$ Color Removal}

In the EC process, the $\mathrm{pH}$ value of the solution plays a fundamental role in the pollutants removal [19]. The initial $\mathrm{pH}$ value was varied from 4 to 10 . The effect of $\mathrm{pH}$ with other factors on \% color removal potency is shown in Figure 2 and Figure 3. The treatment at $\mathrm{pH}$ between 4 and 9 with $\mathrm{Al}$ electrodes has been studied by researchers [20]. It was observed that $\mathrm{pH}$ increases during EC process in acidic medium $(\mathrm{pH} 2.5,4$, and 6) and decreases in the $\mathrm{pH}$ ranges more than $(\mathrm{pH}$ 
8 and 10) due to the $\left(\mathrm{H}^{+}\right)$and $\left(\mathrm{OH}^{-}\right)$consumption and formation during EC process, respectively. During EC process neutralization of $\mathrm{pH}$ of the system describe that [21] the $\mathrm{pH}$ of acidic medium (EC system) increases due to the water hydrolysis and $\mathrm{H}_{2(\text { gas })}$ evolution, thus producing $\mathrm{OH}^{-}$:

$$
2 \mathrm{H}^{+}+2 \mathrm{e}^{-} \rightarrow \mathrm{H}_{2}
$$

Table 2. Experimental runs with responses.

\begin{tabular}{|c|c|c|c|c|c|c|}
\hline $\mathrm{pH}$ & $\mathrm{NaCl}(\mathrm{g})$ & Voltage (V) & $\begin{array}{l}\text { [DYE] } \\
(\mathrm{mg} / \mathrm{L})\end{array}$ & $\mathrm{Y} 1=\mathrm{RR} 223$ & $\mathrm{Y} 2=\mathrm{CBBR} 250$ & $\begin{array}{c}\text { \%COD } \\
\text { Removal }\end{array}$ \\
\hline 8.5 & 3.25 & 6.75 & 30 & 85 & 91 & 93 \\
\hline 8.5 & 3.25 & 6.75 & 50 & 79 & 95 & 87 \\
\hline 8.5 & 1.75 & 6.75 & 30 & 79 & 97 & 89 \\
\hline 8.5 & 1.75 & 6.75 & 50 & 75 & 90 & 79 \\
\hline 7.0 & 2.50 & 8.5 & 40 & 87 & 91 & 92 \\
\hline 7.0 & 2.50 & 8.5 & 40 & 87 & 93 & 93 \\
\hline 5.5 & 3.25 & 6.75 & 30 & 96 & 95 & 91 \\
\hline 5.5 & 1.75 & 6.75 & 30 & 95 & 93 & 92 \\
\hline 5.5 & 1.75 & 6.75 & 50 & 94 & 99 & 94 \\
\hline 8.5 & 1.75 & 10.25 & 30 & 87 & 90 & 91 \\
\hline 5.5 & 3.25 & 10.25 & 50 & 97 & 99 & 96 \\
\hline 5.5 & 1.75 & 10.25 & 30 & 92 & 99 & 87 \\
\hline 5.5 & 3.25 & 10.25 & 30 & 96 & 99 & 93 \\
\hline 7 & 2.5 & 8.5 & 40 & 92 & 98 & 94 \\
\hline 5.5 & 1.75 & 10.25 & 50 & 93 & 98 & 99 \\
\hline 8.5 & 3.25 & 10.25 & 50 & 98 & 99 & 97 \\
\hline 8.5 & 3.25 & 10.25 & 30 & 98 & 99 & 94 \\
\hline 5.5 & 3.25 & 6.75 & 50 & 98 & 99 & 97 \\
\hline 8.5 & 1.75 & 10.25 & 50 & 98 & 99 & 91 \\
\hline 7 & 2.5 & 8.5 & 40 & 91 & 98 & 89 \\
\hline 7 & 4 & 8.5 & 40 & 94 & 98 & 90 \\
\hline 10 & 2.5 & 8.5 & 40 & 93 & 95 & 89 \\
\hline 7 & 1 & 8.5 & 40 & 57 & 74 & 76 \\
\hline 4 & 2.5 & 8.5 & 40 & 93 & 98 & 91 \\
\hline 7 & 2.5 & 5 & 40 & 94 & 94 & 93 \\
\hline 7 & 2.5 & 8.5 & 40 & 94 & 96 & 95 \\
\hline 7 & 2.5 & 8.5 & 40 & 93 & 97 & 95 \\
\hline 7 & 2.5 & 8.5 & 20 & 100 & 100 & 95 \\
\hline 7 & 2.5 & 8.5 & 60 & 93 & 97 & 91 \\
\hline 7 & 2.5 & 12 & 40 & 96 & 99 & 93 \\
\hline
\end{tabular}



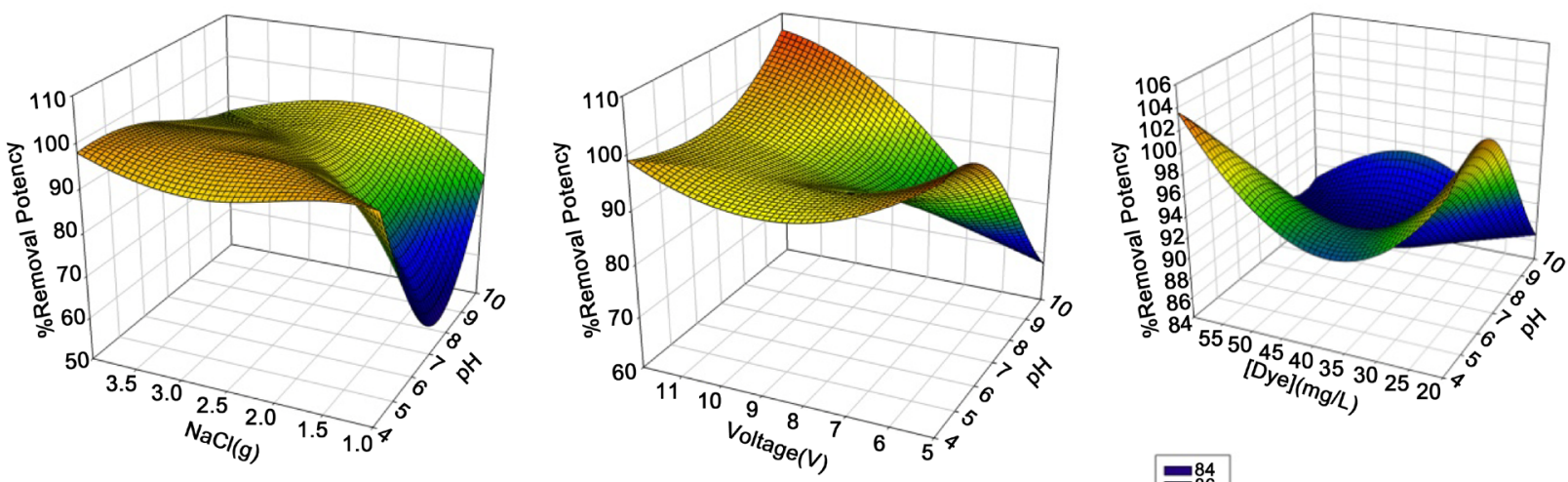

(a)
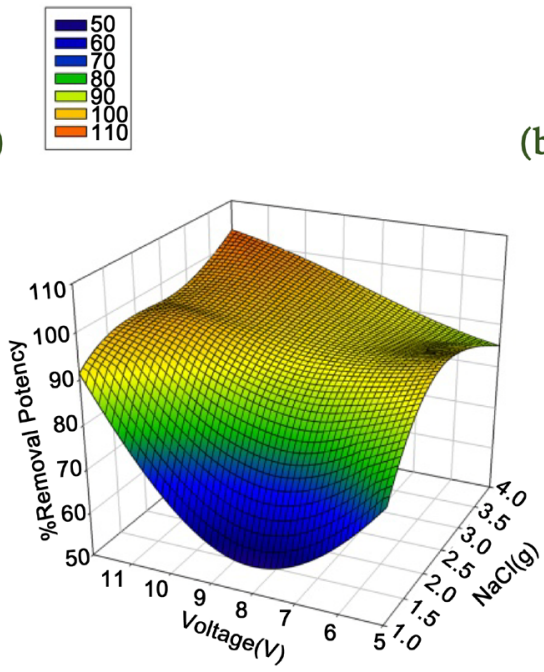

(d)

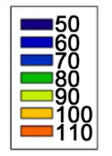

(b)

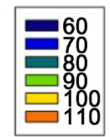

(c)
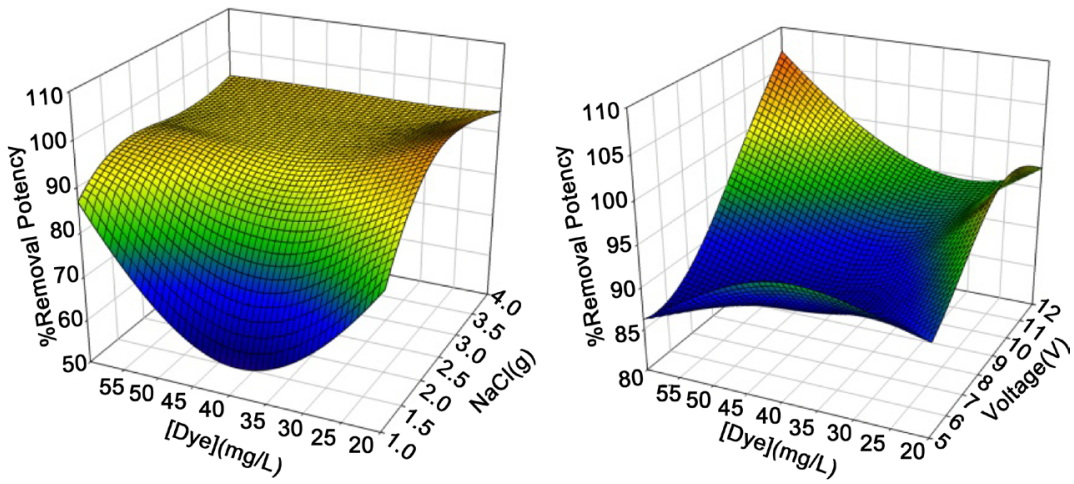

(f)

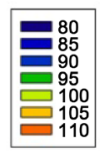

Figure 2. Response surface plots for \% removal of RR223. (a) $\mathrm{pH}$ and $\mathrm{NaCl}$ (g); (b) pH and voltage (V); (c) pH and [Dye] (mg/L); (d) $\mathrm{NaCl}(\mathrm{g})$ and Voltage $(\mathrm{V}) ;(\mathrm{e}) \mathrm{NaCl}(\mathrm{g})$ and [Dye] (mg/L); (f) Voltage (V) and [dye] (mg/L).

The \% color removal of reactive red223 is significantly affecting by the variation in $\mathrm{pH}$ levels as compared to CBBR250.The acidic medium is most favourable for both dyes \% decolourization efficiency. The \% decolourization potency of Coomassie brilliant blue dye in both acidic and alkaline media is virtually same. When $\mathrm{pH}$ is acidified, $\mathrm{H}^{+}$ions neutralize the functional groups (such as phenolic, $\mathrm{OH}^{-}$, and -COO) of organic molecules that are negatively charged; thus, this protonic charge neutralization decreases their solubility in water which facilitate coagulation of molecules. The neutralization due to $\mathrm{pH}$ is the key step of the coagulation process [22].

\subsection{Effect of Amount of Electrolyte on \% Color Removal}

The purpose of addition of electrolyte is to increase the conductance of the solution. Therefore, adding $\mathrm{NaCl}$ as a supporting electrolyte is used to increase the solution conductivity. Consequently, a concentration of $1-4 \mathrm{~g} / \mathrm{L} \mathrm{NaCl}$ is chosen 

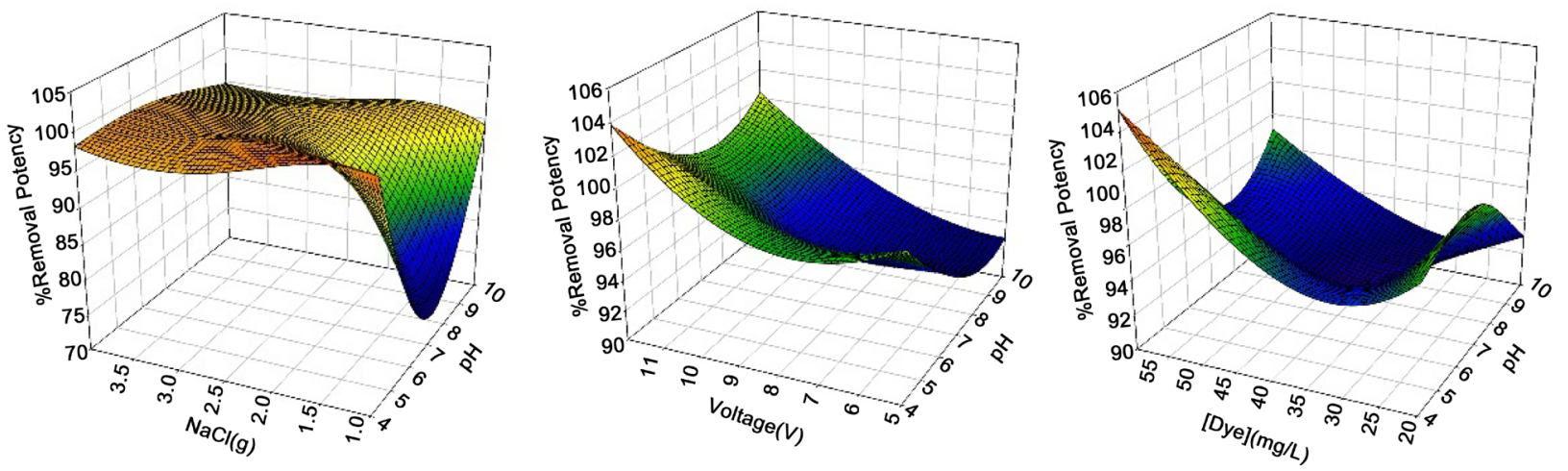

(a)
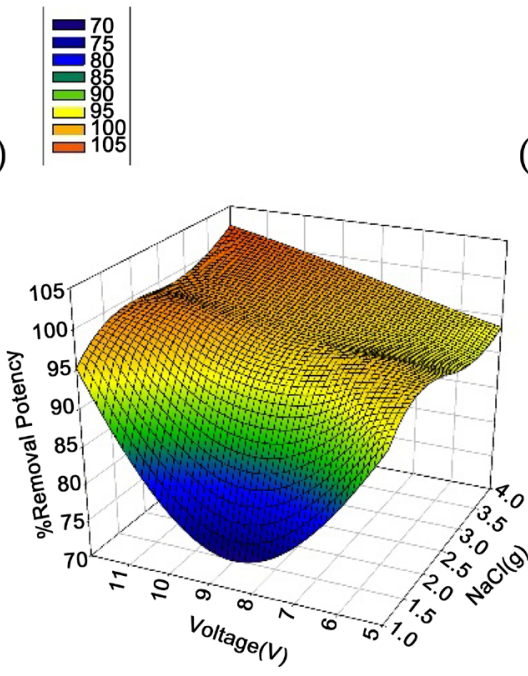

(d)

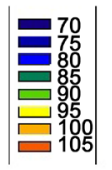

(b)

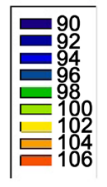

(c)

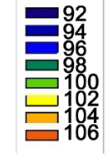

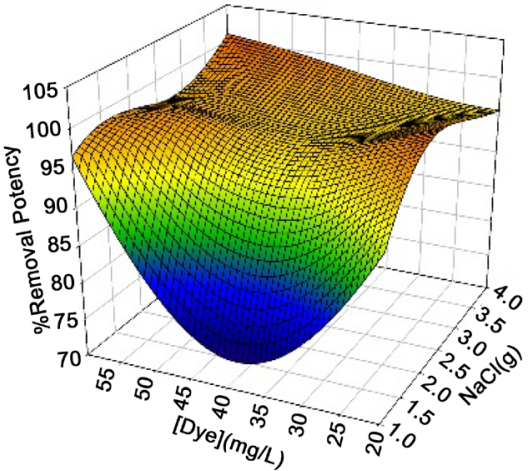

(e)

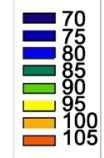

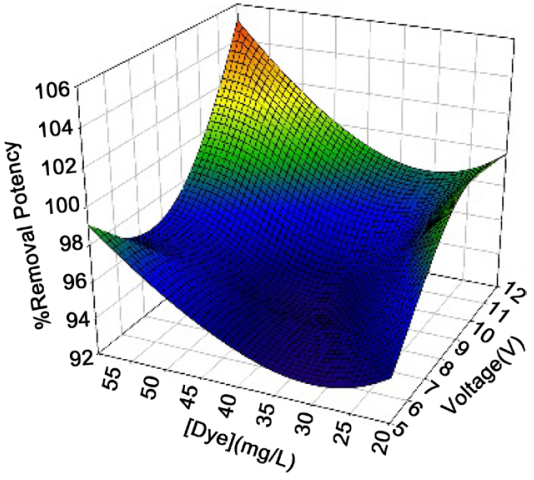

(f)

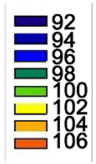

Figure 3. Response surface plots for \%removal of CBBR250. (a) $\mathrm{pH}$ and $\mathrm{NaCl}$ (g); (b) $\mathrm{pH}$ and voltage( $\mathrm{V}$ ); (c) $\mathrm{pH}$ and [Dye] $(\mathrm{mg} / \mathrm{L}) ;(\mathrm{d}) \mathrm{NaCl}(\mathrm{g})$ and Voltage (V); (e) $\mathrm{NaCl}(\mathrm{g})$ and [Dye] (mg/L); (f) Voltage (V) and [dye] (mg/L).

for the experiments. In the case of $1 \mathrm{~g} / \mathrm{L} \mathrm{NaCl}$ the $\%$ color removal efficiency were $57 \%$ and $74 \%$ of RR223 and CBBR250 at neutral pH. While at $4 \mathrm{~g} / \mathrm{L} \mathrm{NaCl}$ the $\%$ decolourization increased upto $98 \%$ for both dyes at buffer conditions. The effect of $\mathrm{NaCl}$ with other factors on \% color removal potency is shown in Figure 2 and Figure 3.

\subsection{Effect of Voltage on \% Color Removal}

The removal of RR223 is significantly affecting due to variation in voltage. At $6.75 \mathrm{~V}$ the color removal potency of RR223 is $79 \%$ and enhanced upto $96 \%$ at 12 $\mathrm{V}$. The removal potency of CBB250 has observed same at all levels of voltage as in Figure 2 and Figure 3.

\subsection{Effect of Dye Concentration on \% Color Removal}

The higher concentration of dye will require high dose of coagulants for coagu- 
lation and coagulants formation in EC process is entirely depend upon the applied voltage and reaction time. So, energy consumption will directly increase the cost of the process.

\subsection{Effect of $\mathrm{pH}$ on \% COD Removal}

At neutral $\mathrm{pH}$ the \% COD removal efficiency is $76 \%$ and at $5.5 \mathrm{pH}$ value increased upto 97\%. The experiments were carried out at different initial $\mathrm{pH}$ values at the vary of $\mathrm{pH} 4.0$ - 10. Generally, the $\mathrm{pH}$ of the medium inclined to increment throughout the method. The vicissitude in $\mathrm{pH}$ depends on the slightly electrode material and initial $\mathrm{pH}$ value. At low $\mathrm{pH}, \mathrm{CO}_{2}$ is dissolved into the solution and discharge of $\mathrm{H}_{2}$ evolution, causing a $\mathrm{pH}$ increase. The effect of initial $\mathrm{pH}$ on the COD abstraction efficiencies is given in Figure 4. The maximum abstraction rates were obtained at the cessation of a $50 \mathrm{~min}$ reaction time. As optically discerned, for $\mathrm{pH}<6$, between $91 \%$ and $94 \%$ for COD abstraction. COD

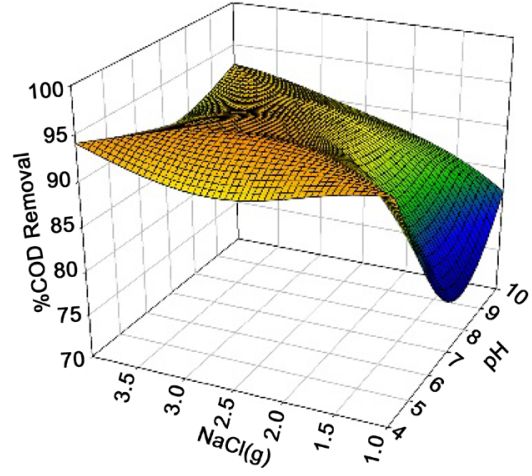

(a)

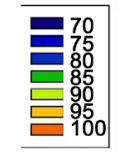

(b)
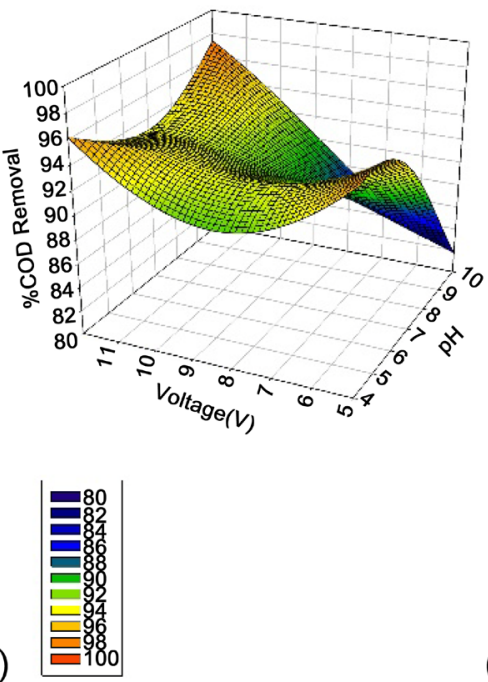

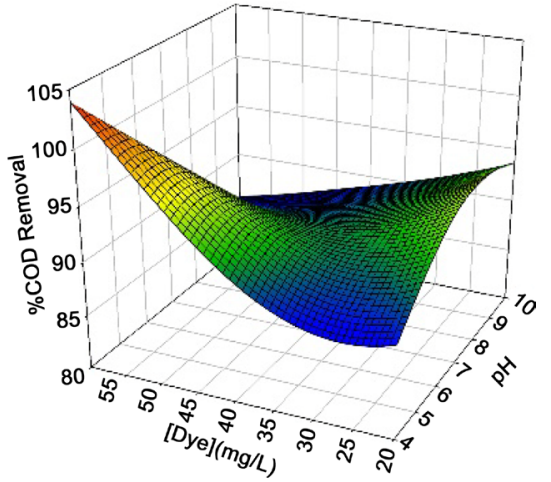

c) $\begin{array}{r}\sigma_{80}^{80} \\ 85 \\ \sigma_{90} \\ \underline{V}_{100} \\ 105\end{array}$
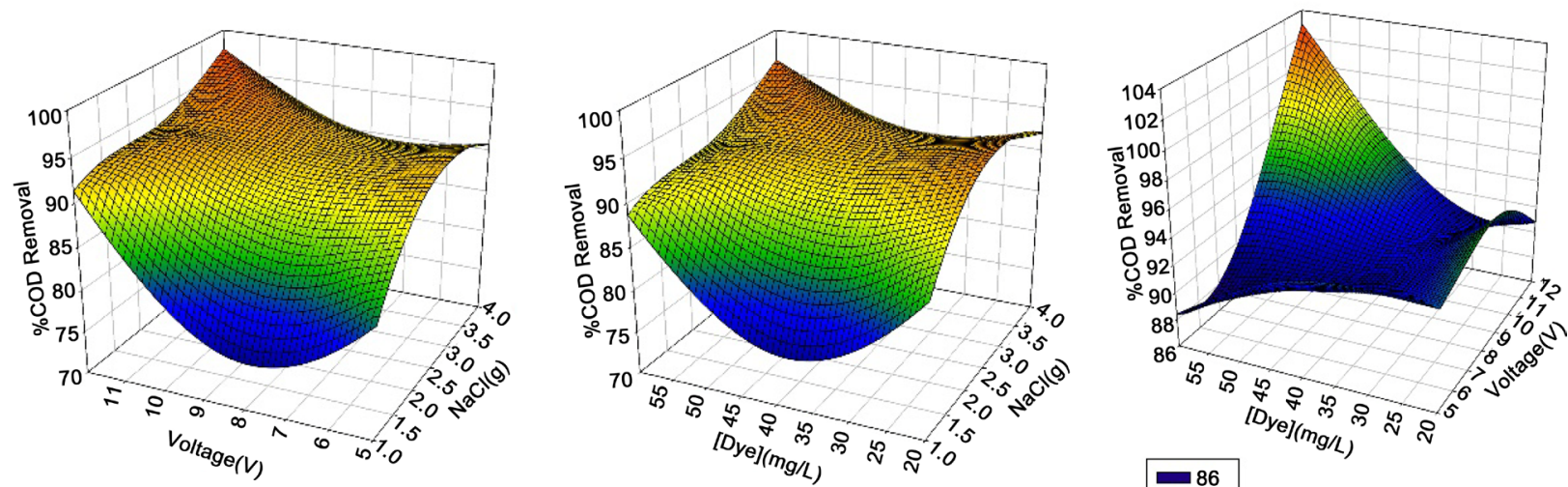

(d)

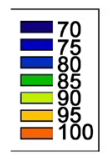

(e)

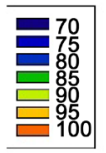

(f)

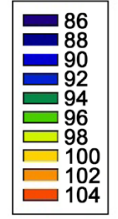

Figure 4. Response surface plots for \% COD removal. (a) $\mathrm{pH}$ and $\mathrm{NaCl}(\mathrm{g})$; (b) $\mathrm{pH}$ and Voltage (V); (c) pH and [Dye] (mg/L); (d) $\mathrm{NaCl}(\mathrm{g})$ and Voltage (V); (e) $\mathrm{NaCl}(\mathrm{g})$ and [Dye] (mg/L); (f) Voltage (V) and [dye] (mg/L). 
abstractions drop dramatically at $\mathrm{pH}>6$. The highest abstraction efficiencies have been obtained with aluminum in acidic medium with $\mathrm{pH}<6$. The COD from textile wastewater utilizing aluminum electrodes are mainly removed by electrocoagulation, while the COD abstraction by iron electrodes is due to the collective effect of electrocoagulation and electrooxidation. Solution $\mathrm{pH}$ is one of the most consequential parameters for EC process [23]. So, it is adjusted in the range from 4 to 10 by integrating sodium hydroxide or sulfuric acid solution to investigate the effect of $\mathrm{pH}$ on process performance. The process efficiency depends vigorously on $\mathrm{pH}$ value of the solution. Especially, low $\mathrm{pH}$ value increases the abstraction efficiencies, because $\mathrm{pH}$ values of the solution elevate during electrolysis process and after a certain point it reaches auspicious $\mathrm{pH}$ value for $\mathrm{Al}(\mathrm{OH})_{3}$ precipitation [24]. The best COD removals could be obtained in acidic $\mathrm{pH}$ value with aluminum electrodes [25]. In addition, they reported that when solution $\mathrm{pH}$ was increased to 7 , removal rates decreased dramatically. When aluminum is used as the electrode material, acidic $\mathrm{pH}$ values are more convenient for the removal kinetics due to predominant form of $\mathrm{Al}(\mathrm{OH})_{3}(\mathrm{~s})$. The result is in accordance with kindred studies in literature [26] [27].

\subsection{Effect of Amount of Electrolyte on \% COD Removal}

The conductivity of the textile wastewater was adjusted to the desired levels by integrating an opportune amount of electrolyte. The experimental conditions were: initial $\mathrm{pH}$ of $4-10$; $[\mathrm{NaCl}] 1-4 \mathrm{~g} / \mathrm{L}$, Voltage $(5-12 \mathrm{~V})$; and dye concentration $(20-60 \mathrm{mg} / \mathrm{L})$. If anode potential is adequately high, secondary reactions may occur additionally, such as direct oxidation of organic compounds and of $\mathrm{Cl}^{-}$ions present in wastewater [28]:

$$
2 \mathrm{Cl}^{-} \rightarrow \mathrm{Cl}_{2}+2 \mathrm{e}^{-}
$$

Thus, above generated chlorine gas oxidizes dye molecules. The conductivity of the wastewater is adjusted to the desired levels by adding an appropriate amount of $\mathrm{NaCl}$. This adjustment has shown negligible effect on the initial $\mathrm{pH}$ of the wastewater, approximately $0.3 \mathrm{pH}$ units, with mean $\mathrm{pH}$ value of 6.8 . It is clear that, for aluminum, the energy consumption is higher and electrode consumption is lower. For both electrodes, the energy and electrode consumptions decrease with increasing wastewater conductivity. It is observed that higher conductivity favors high process efficiency.

\subsection{Effect of Voltage on \% COD Removal}

In fact, Voltage is directly proportional to current. When current increases, there is an increase in aluminium dissolution. So, enhances the formation of hydroxide $\mathrm{Al}(\mathrm{OH})_{3}$. For long electrolysis times, the structure of the sludge may change, altering the efficiency of pollution removal and the settle-ability and floatability properties of the flocs. The effect of applied voltage to the electrocoagulation cell was investigated by varying the voltage level from 5 to $12 \mathrm{~V}$. Each experimental trial kept the initial $\mathrm{pH}$ according to design runs and reaction time of approx- 
imately $50 \mathrm{~min}$. The COD removal potency was observed $76 \%$, when $\mathrm{NaCl}=1 \mathrm{~g}$ and Voltage $=8.5 \mathrm{~V}$ and 93\% COD removal potency was observed, when $\mathrm{NaCl}=$ $2.5 \mathrm{~g}$ voltage $=12 \mathrm{~V}$ at neutral $\mathrm{pH}$. It is agreed from Pareto chart too that voltage and $\mathrm{pH}$ combine significantly affecting the \% COD removal potency.

Figure 4 shows that increasing the voltage from 3 to $5 \mathrm{~V}$ causes the increasing removal percentage and then by more enhancement of voltage, the percentage of removal of COD declines. Effect of voltage can be described according to reactions that occur during the process. Mechanism of reactions and behavior of oxide anodes (MOx) was proposed by Comninellis [29]. At the first step, discharge of water occurs to produce hydroxyl radicals. There are two states of active oxygen; physically adsorbed active oxygen (adsorbed hydroxyl radicals $\mathrm{MOx}(\mathrm{OH})$ ) and chemisorbed active oxygen (oxygen in the oxide lattice $\mathrm{MO}_{\mathrm{x}+1}$ ) [30]. In the presence of oxidizable organics, combustion and conversion reactions may take place Equations ((10) and (11)). These oxidation reactions compete with side reactions of oxygen evolution Equations ((12) and (13));

$$
\begin{gathered}
\mathrm{MO}_{\mathrm{X}}\left(\mathrm{HO}^{\circ}\right)+\mathrm{RH} \rightarrow \mathrm{MO}_{\mathrm{X}}+m \mathrm{CO}_{2}+n \mathrm{H}_{2} \mathrm{O}+\mathrm{H}^{+}+\mathrm{e}^{-} \\
\mathrm{MO}_{\mathrm{X}+1}+\mathrm{RH} \rightarrow \mathrm{MO}_{\mathrm{X}}+\mathrm{ROH} \\
\mathrm{MO}_{\mathrm{X}}\left(\mathrm{HO}^{\circ}\right) \rightarrow \mathrm{MO}_{\mathrm{X}}+\frac{1}{2} \mathrm{O}_{2}+\mathrm{H}^{+}+\mathrm{e}^{-} \\
\mathrm{MO}_{\mathrm{X}+1} \rightarrow \mathrm{MO}_{\mathrm{X}}+\frac{1}{2} \mathrm{O}_{2}
\end{gathered}
$$

Electrochemical oxidation of organics occurs theoretically before oxygen evolution [30]. By applying higher voltage concomitant oxygen evolution takes place that results in decreasing efficiency of organic oxidation. On the other hand, performing the process at higher voltages causes oxidation of poisoning products formed at the anode surface.

\subsection{Effect of Dye Concentration on \% COD Removal}

In the study, another investigated parameter is initial dye concentration because wastewater properties change daily or even hourly. So, initial concentration was chosen as one of the parameters affecting the treatment efficiency of the system. According to the result, high initial wastewater concentration decreases COD removal efficiencies, and this could be expounded by the high soluble COD content of the wastewater. In addition, this is possibly due to the formation of inadequate number of aluminum hydroxide complexes by the electrode at a given conductivity and cell voltage to coagulate the extortionate number of pollutant molecules at higher concentration. Soluble and miscible compounds that may not react with engendered metal ions will not be abstracted by EC and they will remain in solution. Just an iota can be adsorbed or absorbed on the floc and may consequently be abstracted incidentally. In brief, it can be verbally expressed that COD abstraction efficiency and its variability will depend on the formation of floc, which conventionally occurs at felicitous values of solution $\mathrm{pH}$ [31]. It was 
observed that at same system conditions when concentration of dyes was 30 ppm, the \% COD abstraction potency was $93 \%$ and decremented upto $87 \%$ when dyes system concentration was victualed $50 \mathrm{ppm}$. The EC process can facilely abstract particulate COD, it may abstract just a scintilla of soluble COD via sorption mechanism on the floc surface [32].

\section{CCD Experimental Design}

The experimental and the predicted responses correlation is quantitatively evaluated by coefficient $\left(R^{2}\right)$. The obtained $R^{2}$ values suggest good agreement to the observed results since this indicates that $76.38 \%$ and $58.36 \%$ variation in $\%$ color removal is explained by the model. The goodness of a fit is measured by the Adjusted $R^{2}$ (Adj- $R^{2}$ ) value as shown in Table 3 design by Minitab 17 software.

The independent variable on the horizontal axis is plotted against the residuals on the vertical axis in residual plots. If the points in a residual plot are randomly dispersed around the horizontal axis, a linear regression model is fitted for the data; otherwise, a non-linear model is more appropriate. The normality of the residuals is studied by Normal probability plots. The observed residuals are plotted against the expected values, given by a normal distribution in Figure 5. The residuals from the analysis should be normally distributed. In practice, if number of observation is large, moderate divergence from normality do not critically influence the results. The normal probability plot of the residuals should follow a straight line to fit the linear model. Trends observed in Figures 5(a)-(c) reveal reasonably well-behaved residuals for \% color and COD removal. Based on these plots, the residuals appear to be randomly scattered about zero. Figures 5(a)-(c) illustrate the residuals in the order of the corresponding observations. It shows that the residuals in the plot fluctuate in an arbitrary pattern around the center line.

\subsection{Pareto Charts Analysis}

The Pareto plot helps to identify the significant factors that influence the target response. Linear, quadratic and interactive significance of factors on response are identified. The amount of electrolyte, $\mathrm{pH}$ and dyes concentration is the significant factors that are influencing the response. The amount of electrolyte factor has a greater effect on response compared to the other factors. This is due to

Table 3. Model Summary for \% color and COD removals.

\begin{tabular}{cccc}
\hline Statistical Variable & RR223 & CBBR250 & \% COD removal \\
\hline S (Root Mean Square Error) & 6.154 & 4.713 & 3.134 \\
$\mathbf{R}^{2}$ & $76.38 \%$ & $58.36 \%$ & $79.27 \%$ \\
$\mathbf{R}^{2}$ (Adj) & $51.07 \%$ & $13.76 \%$ & $57.07 \%$ \\
R-sq (pred) & $0.00 \%$ & $0.00 \%$ & $0.00 \%$
\end{tabular}




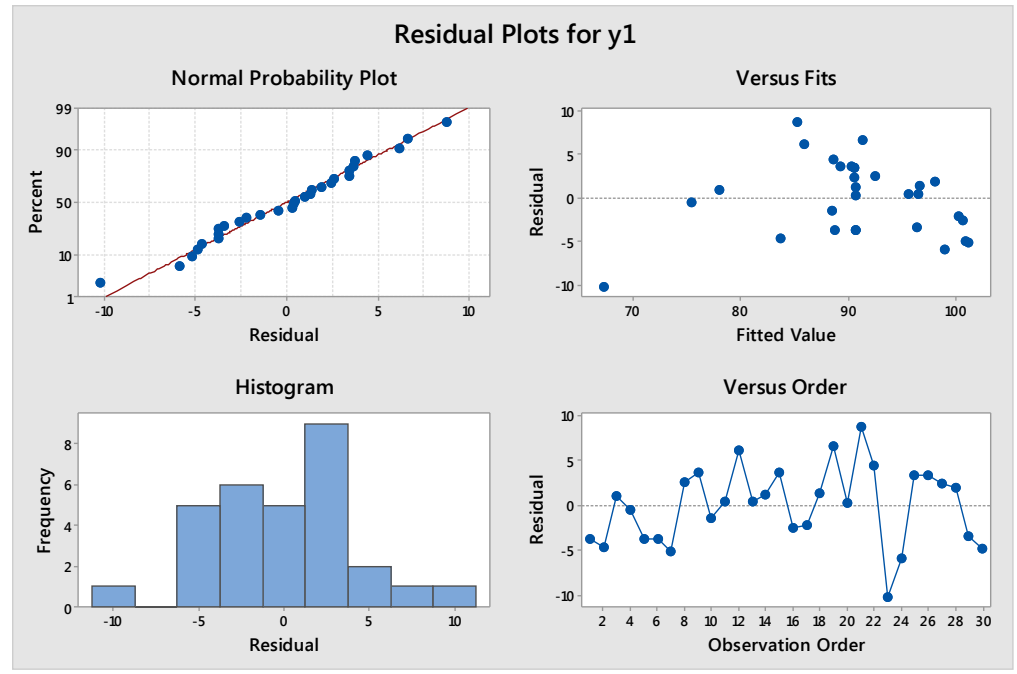

(a)

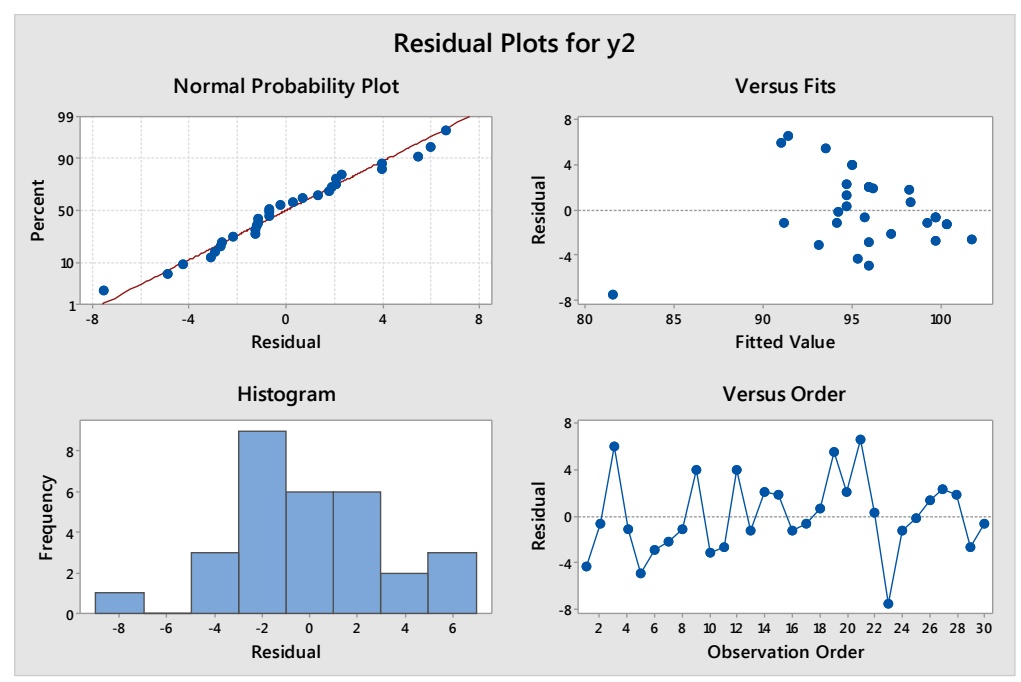

(b)

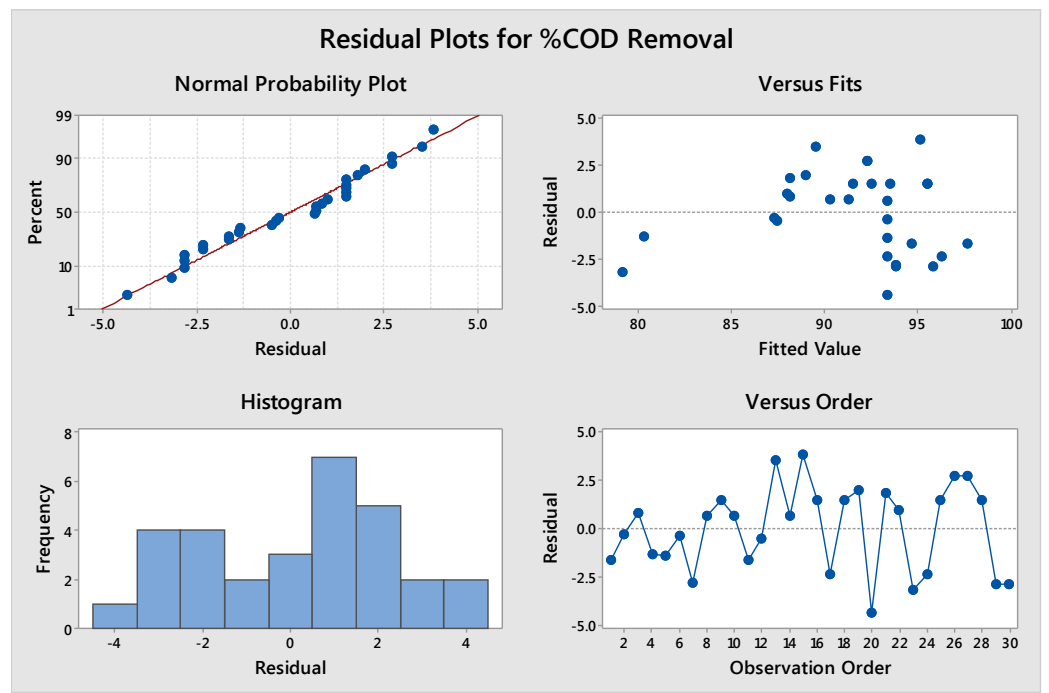

(c)

Figure 5. Residual plots of (a) RR223 dye (b) CBBR250 (c) \% COD removal potency. 
the fact that $\mathrm{NaCl}$ increases the conductivity of the EC system and enhances the $\%$ color and COD removal. The Pareto chart related to \% dye and COD removal potency are given in Figures 6 (a)-(c).

\subsection{ANOVA Test}

ANOVA test is performed to study the influence of all factors on target response. Statistical significance of the model equation and model terms was evaluated by F-test and ANOVA [33]. Sum of squares (SS), DOF (degree of freedom), mean of square (MS), and associated F-test of importance (F) can be calculated as follows:

$$
S S_{A}=\sum_{i=1}^{k_{A}}\left(A_{i}^{2} / n A i\right)-T^{2} / N
$$

Description of abbreviations is as follows: " $k_{A}$ " is the number of the levels of factor A, " $n A \ddot{i}$ " is the number of all observations at level " " of factor A, $A_{i}$ is the sum of all observations of level " $i$ " of factor $A$ and $T$ is the sum of all observations. SS of error is computed using the following equation:

$$
S S e=S S_{T}-\left(S S_{A}+S S_{B}+\cdots\right)
$$

where SST is the total SS:

$$
S S_{T}=\sum_{i=1}^{n}\left(Y_{i}^{2}\right)-T^{2} / N
$$

where " $y_{i}$ " is the observation of " $i$ ". MS is calculated by dividing the sum of squares by the degrees of freedom. $\mathrm{DOF}_{\mathrm{A}}$ is estimated by $\mathrm{DOF}_{\mathrm{A}}=k_{A}-1$. F value is calculated as follows (Gönder et al. 2010):

$$
F_{A}=M S_{A} / M S e
$$

$M S e$ is the variance of error [34].

The analysis of variance (ANOVA) is presented in Table 4. If the model is a good predictor of the experimental results, F-value should be greater than the tabulated value of F-distribution for a certain number of degrees of freedom in the model at a level of significance $\alpha$. The p-value $<0.05$ for RR223 so it is confirming the adequacy of the model fitted. A, B, C, B ${ }^{2}$ and AC are significantly affecting the response of RR223. The p-value $>0.05$ for coommassie brilliant blue R250 is indicating insignificance of the model. $B, B^{2}$ are the terms that are significantly effecting the response of the target response of coommassie brilliant blue. p-value $<0.05$ for \% COD removal its mean model is fitted for the response.B. $\mathrm{B}^{2}$ and $\mathrm{AD}$ are the significant terms for $\% \mathrm{COD}$ removal potency which are agreed from pare to chart too. The student $-t$ distribution and the corresponding P-values, along with the parameter estimate, are given in Table 5. The P-values were utilized as an implement to check the consequentiality of each of the coefficients, which in turn, are compulsory to understand the pattern of the mutual interactions between the variables studied. The more immensely colossal the magnitude of $\mathrm{t}$-value and more minute $\mathrm{P}$-value, the more paramount is the corresponding coefficient [35]. 


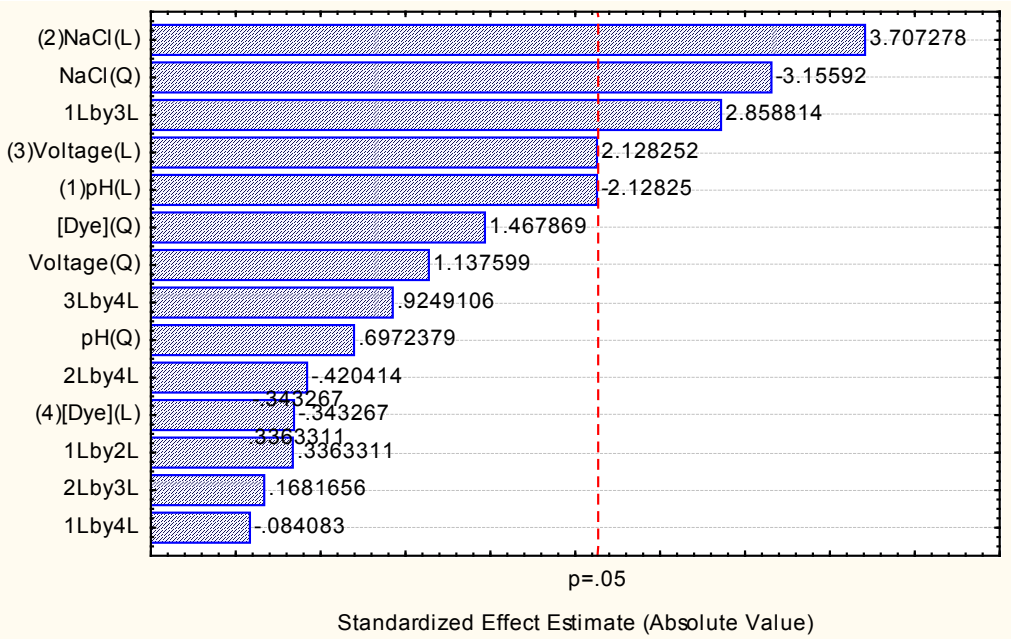

(a)

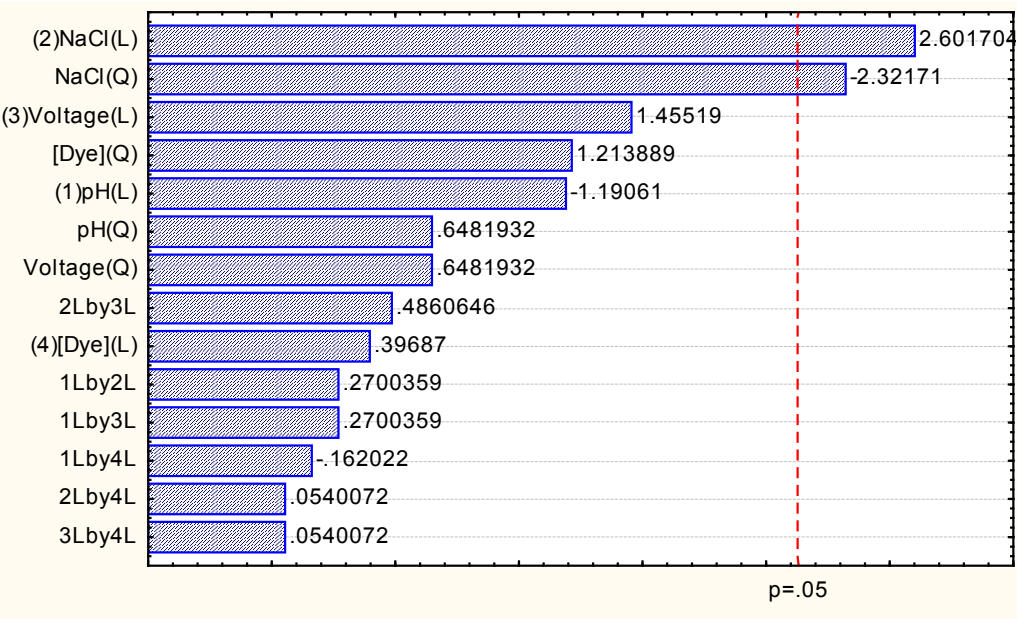

Standardized Effect Estimate (Absolute Value)

(b)

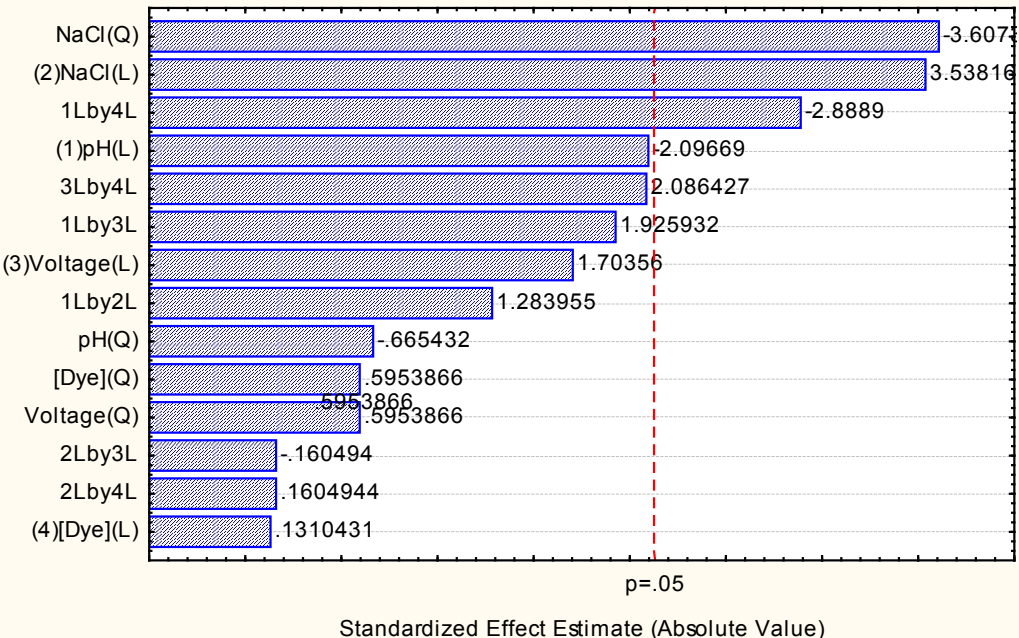

(c)

Figure 6. The Pareto chart of \% color removal. (a) Reactive red223; (b) Coomassie brilliant blue R250; (c) \% COD removal potency. 
Table 4. Analysis of variance for EC process for binary dye removal potency.

\begin{tabular}{|c|c|c|c|c|c|c|}
\hline Response & Source & DF & Adj SS & Adj MS & F-Value & P-Value \\
\hline \multirow{5}{*}{ RR223 } & Model & 15 & 1714 & 114.3 & 3.020 & 0.023 \\
\hline & Error & 14 & 530.3 & 37.88 & * & * \\
\hline & Lack-of-Fit & 10 & 509.0 & 50.90 & 9.580 & 0.022 \\
\hline & Pure Error & 4 & 21.25 & 5.312 & * & * \\
\hline & Total & 29 & 2245 & * & * & * \\
\hline \multirow{5}{*}{ CBBR250 } & Model & 15 & 436.0 & 29.06 & 1.310 & * \\
\hline & Error & 14 & 311.0 & 22.21 & * & * \\
\hline & Lack-of-Fit & 10 & 272.5 & 27.25 & 2.830 & 0.164 \\
\hline & Pure Error & 4 & 38.50 & 9.625 & * & * \\
\hline & Total & 29 & 747.0 & * & * & * \\
\hline \multirow{5}{*}{ COD } & Model & 15 & 526.0 & 35.06 & 3.57 & 0.011 \\
\hline & Error & 14 & 137.5 & 9.823 & * & * \\
\hline & Lack-of-Fit & 10 & 123.5 & 12.35 & 3.53 & 0.118 \\
\hline & Pure Error & 4 & 14.00 & 3.500 & * & * \\
\hline & Total & 29 & 663.5 & * & * & * \\
\hline
\end{tabular}

Table 5. Student $\mathrm{t}$ and $\mathrm{p}$ values for significant operational parameters.

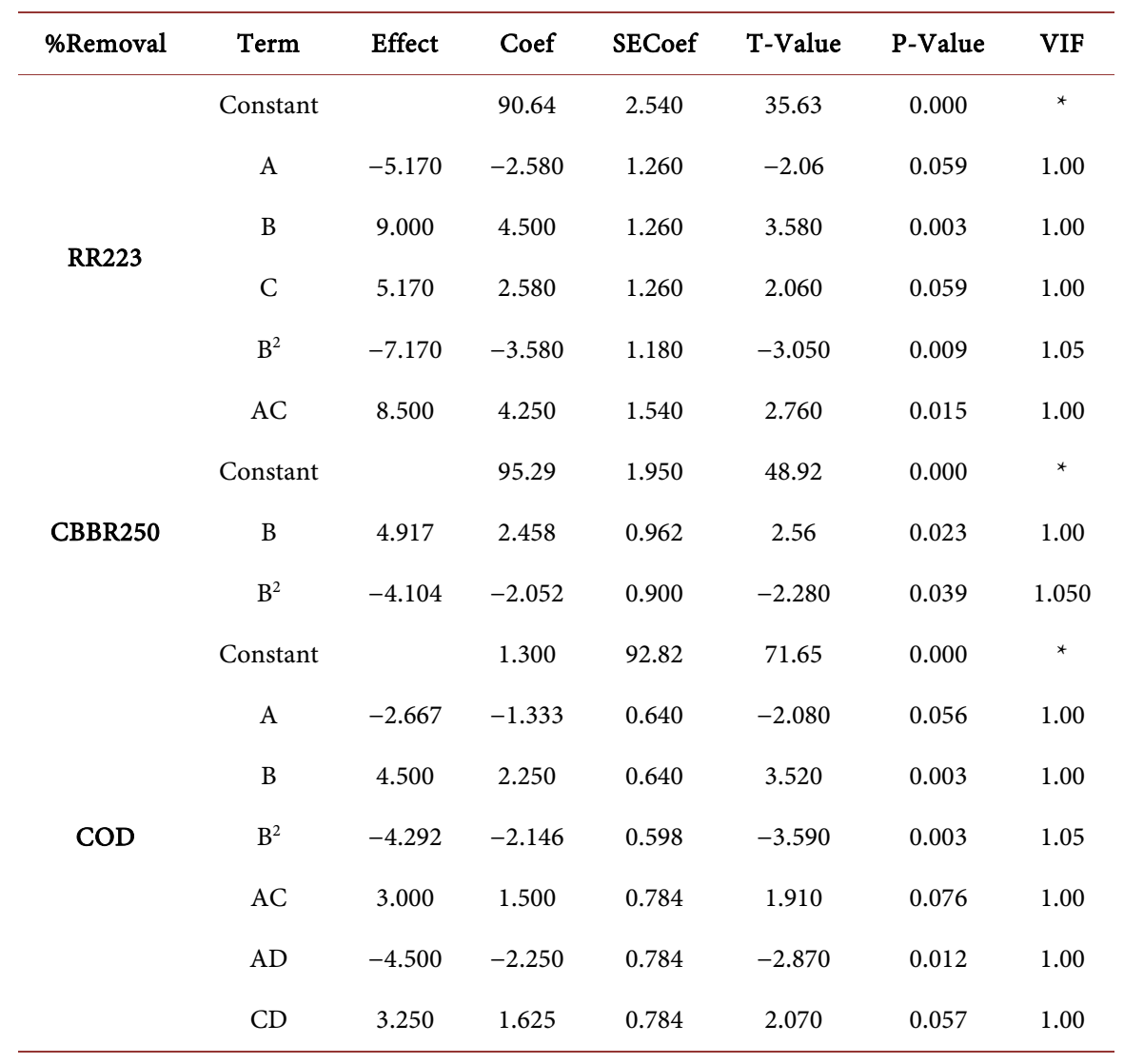




\subsection{Regression Equations}

Based on second order polynomial model, an empirical relationship between the response and independent variables was attained and expressed by the following second-order polynomial equations:

$$
\begin{aligned}
\mathrm{Y}_{1(\mathrm{RR} 223)}= & 235.6-21.2 \mathrm{~A}+36.5 \mathrm{~B}-20.65 \mathrm{C}-1.78 \mathrm{D}+0.352 \mathrm{AA} \\
& -6.37 \mathrm{BB}+0.422 \mathrm{CC}+0.0167 \mathrm{DD}+0.44 \mathrm{AB}+1.619 \mathrm{AC} \\
& -0.008 \mathrm{AD}+0.19 \mathrm{BC}-0.083 \mathrm{BD}+0.0786 \mathrm{CD} \\
\mathrm{Y}_{2(\mathrm{CBBR} 250)}= & 124.1-5.52 \mathrm{~A}+15.6 \mathrm{~B}-4.44 \mathrm{C}-0.78 \mathrm{D}+0.255 \mathrm{AA} \\
& -3.65 \mathrm{BB}+0.187 \mathrm{CC}+0.01073 \mathrm{DD}+0.28 \mathrm{AB}+0.119 \mathrm{AC} \\
& -0.0125 \mathrm{AD}+0.429 \mathrm{BC}+0.008 \mathrm{BD}+0.0036 \mathrm{CD} \\
\% \mathrm{COD} \text { Re moval }= & 106.3+0.49 \mathrm{~A}+15.99 \mathrm{~B}-8.82 \mathrm{C}-0.056 \mathrm{D}-0.176 \mathrm{AA} \\
& -3.81 \mathrm{BB}+0.116 \mathrm{CC}+0.00354 \mathrm{DD}+0.889 \mathrm{AB}+0.571 \mathrm{AC} \\
& -0.1500 \mathrm{AD}-0.095 \mathrm{BC}+0.017 \mathrm{BD}+0.0929 \mathrm{CD}
\end{aligned}
$$

\subsection{Optimization of Parameters}

The goals of the optimization of EC system are to increase the response of color removal potency of two dyes. To solve this type of multi-objective optimization drawback, Derringer and Suich recommended the desirability perform Equation (21) that is one in all the foremost appropriate ways. The overall desirability function, $D$, is the mean value of the individual desirability functions:

$$
D=\left(\prod_{i=1}^{k} d_{i}\right)^{1 / k}
$$

with $d_{i}$ denoting the individual desirability function for every response, and $k$ the number of responses. The purpose of this function is to maximize the responses due to factors levels within the selected ranges. Experimental tests are performed to verify the predicted values of responses at optimum values. The algorithm of multi-objective optimization Minitab software sanctioned us to obtain the prognosticated optimal values. Three attestation runs were carried out in order to check experimentally the optimal point to get predicted response. The optimal presaged values are in good accordance with the experimental ones. Based on these results, a central composite design can be developed in order to optimize the EC system. This process involves three major steps: performing the statistically designed experiments, estimating of coefficients in the proposed model and predicting the response of process and checking the validity of the model. The main objective of the optimization in this work is to determine the optimum values of EC process variables for RR223 and coomassie brilliant blue decolorization. The desired goal in term of decolorization efficiency and \% COD removal potency were defined as "maximize" to achieve highest treatment performance. The optimum values of the process variables for the maximum decolorization efficiency and \% COD removal potency are shown in Table 6. It implicatively insinuates that the strategy used to optimize the decolorization conditions and \% COD abstraction potency and to obtain the maximal for the EC 
Table 6. The result obtained at optimum values.

\begin{tabular}{ccccccc}
\hline & \multicolumn{3}{c}{ Optimum values } & \multicolumn{3}{c}{ Result at optimum values } \\
\cline { 2 - 7 } $\begin{array}{c}\text { Operational } \\
\text { parameters }\end{array}$ & $\begin{array}{c}\text { \%Color } \\
\text { removal } \\
\text { of RR223 }\end{array}$ & $\begin{array}{c}\text { \%Color } \\
\text { removal of } \\
\text { CBBR250 }\end{array}$ & $\begin{array}{c}\text { \% COD } \\
\text { removal }\end{array}$ & $\begin{array}{c}\text { \%Color } \\
\text { removal } \\
\text { of RR223 }\end{array}$ & $\begin{array}{c}\text { \%Color } \\
\text { removal of } \\
\text { CBBR250 }\end{array}$ & $\begin{array}{c}\text { \% COD } \\
\text { removal }\end{array}$ \\
\hline $\begin{array}{c}\text { pH } \\
\text { Amount of } \\
\text { electrolyte }\end{array}$ & 4 & 4 & 4 & & & \\
Voltage & 12 & 3 & 1 & $89 \%$ & $94 \%$ & $100 \%$ \\
[Dyes] & 60 & 12 & 5 & & & \\
\hline
\end{tabular}

process of RR223 and Coomassie brilliant blue solutions is prosperous [36].

\subsection{Main Interaction Plots}

Observation of main interaction plots clearly showing that operational parameters are not linear to experimental mean lines of responses. Its mean factor is significantly affecting the response. Interactions plots could be acclimated to compare the relative vigor of the responses due to factors. The following Figures 7 (a)-(c) are the main interaction plots for $\%$ dye and COD removal potency.

\subsection{Full Interaction Plots}

These are the plot between variables at a time and corresponding response is premeditated. This plot shows response means for the levels of one factor on the $\mathrm{x}$-axis and a separate line for each level of another factor. The parallel lines mean that no variation in target responses due to amendment in factors levels. Moreover, if the response slope is higher than means additional robust interaction was present among the levels of factors for the target response additionally these plots are reciprocal to ANOVA. In addition, interaction plots are very useful and showing significant interaction is present among factors for the responses. Figures $8(a)-(c)$ are representing full interaction plots for $\%$ dye and COD removal potency.

\subsection{Kinetic Study}

The First order and second order kinetics model was utilized, which are represented as follows:

$$
\begin{gathered}
\ln [A] t=\ln A o-k \cdot t \\
\frac{1}{[A] t}=k \cdot t+\frac{1}{[A] o}
\end{gathered}
$$

The kinetic parameters of respective dyes system and energy consumption during the process is represented in Table 7.

\subsection{FTIR Studies and Characterization of Synthesized Sludge}

Under the optimum conditions, the sludge mass engenderment rate for both dye 


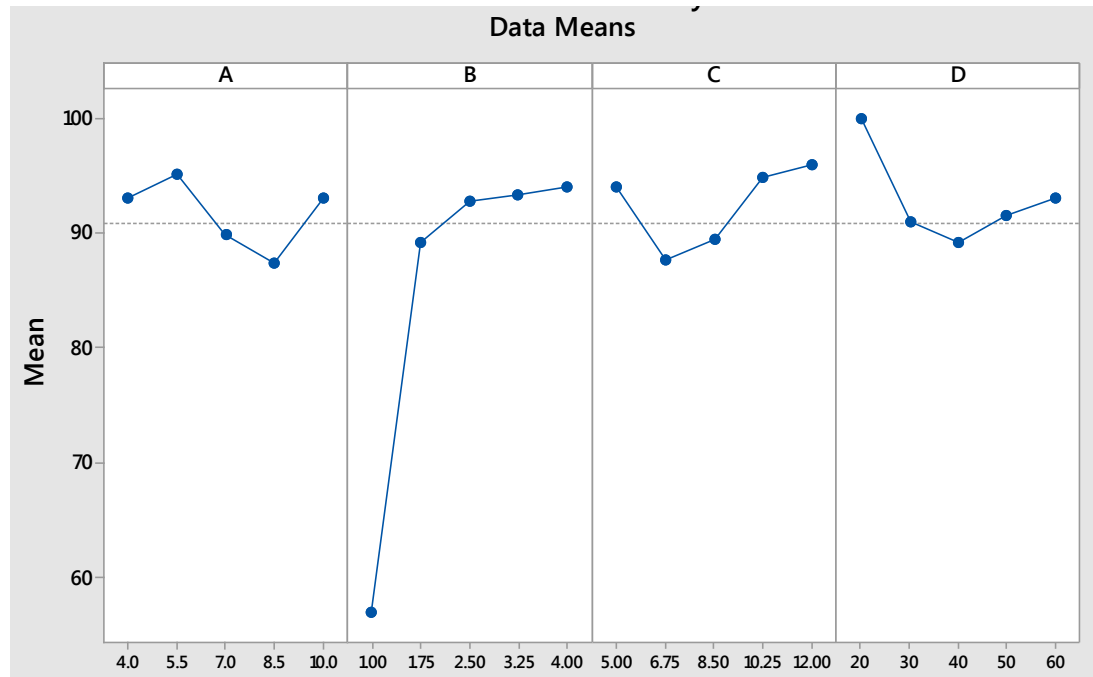

(a)

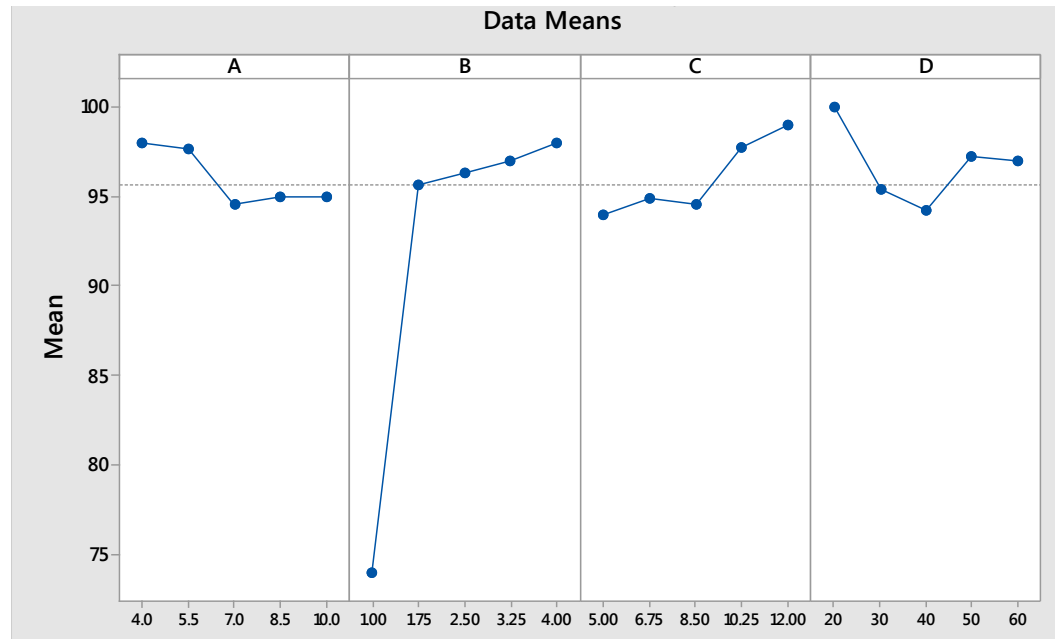

(b)

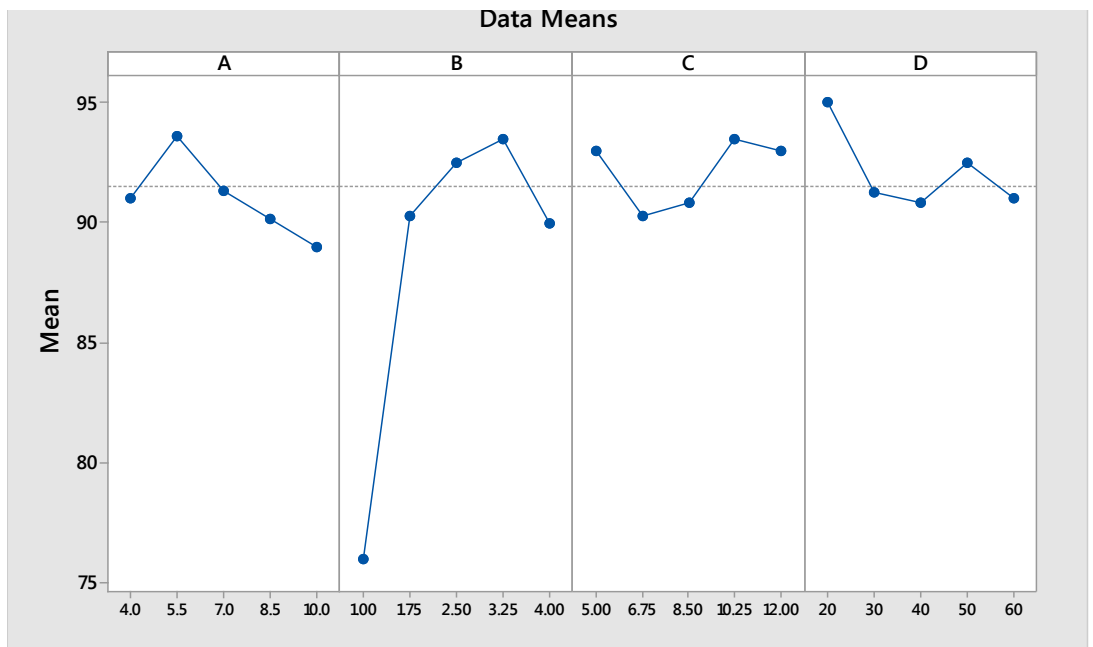

(c)

Figure 7. Main interaction plots. (a) \% color removal of RR223; (b) \%Color removal potency CBBR250; (c) \% COD removal potency. 


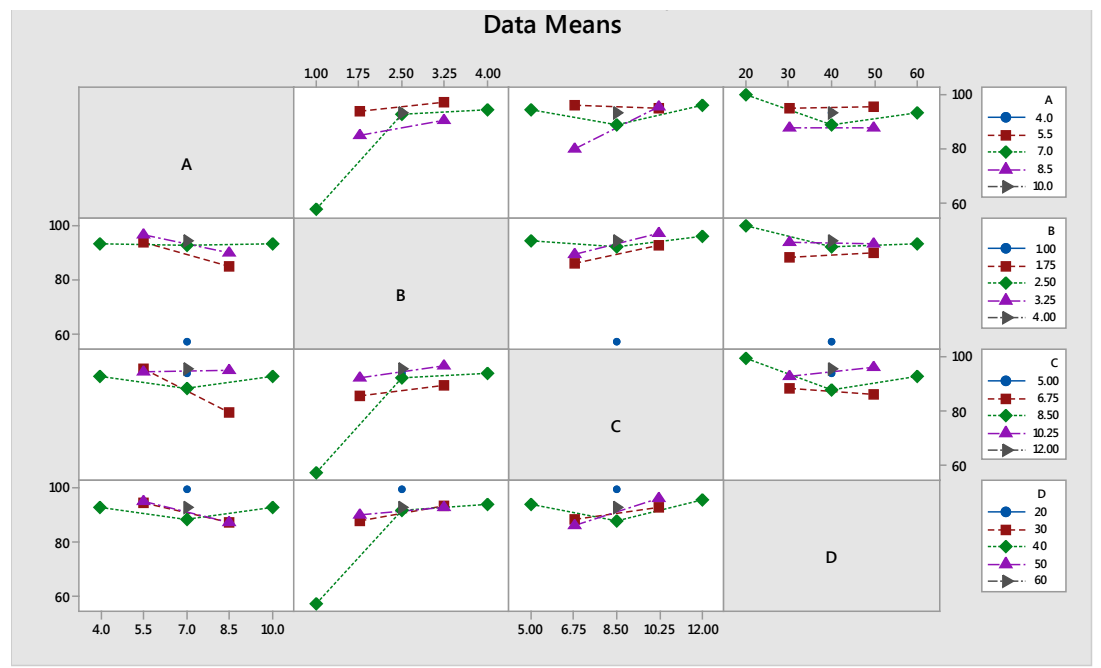

(a)

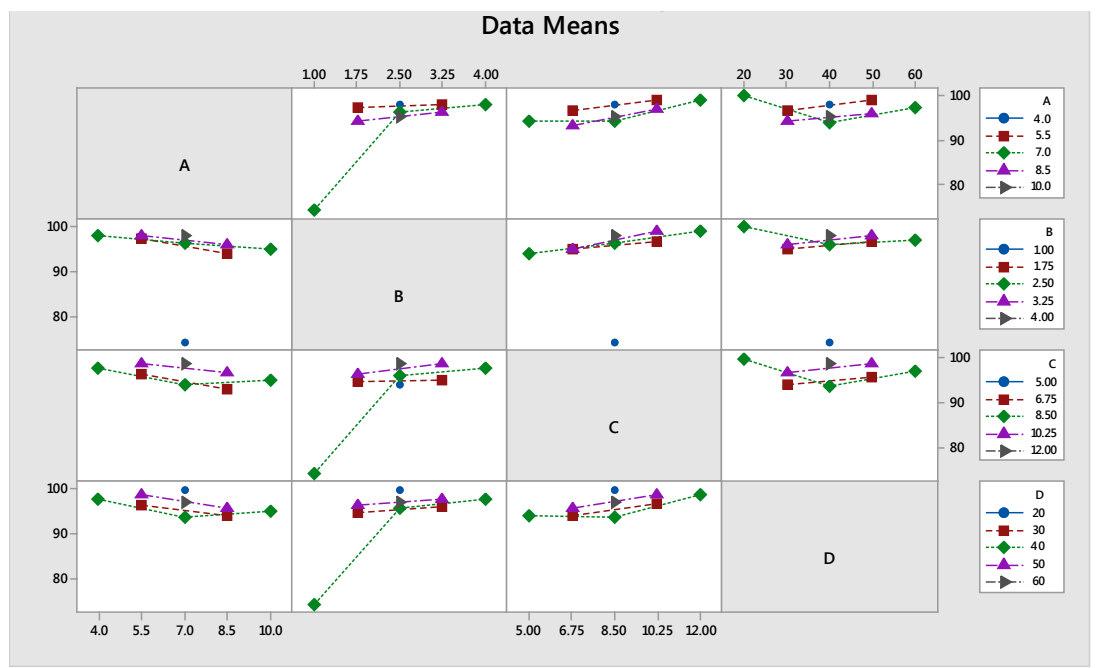

(b)

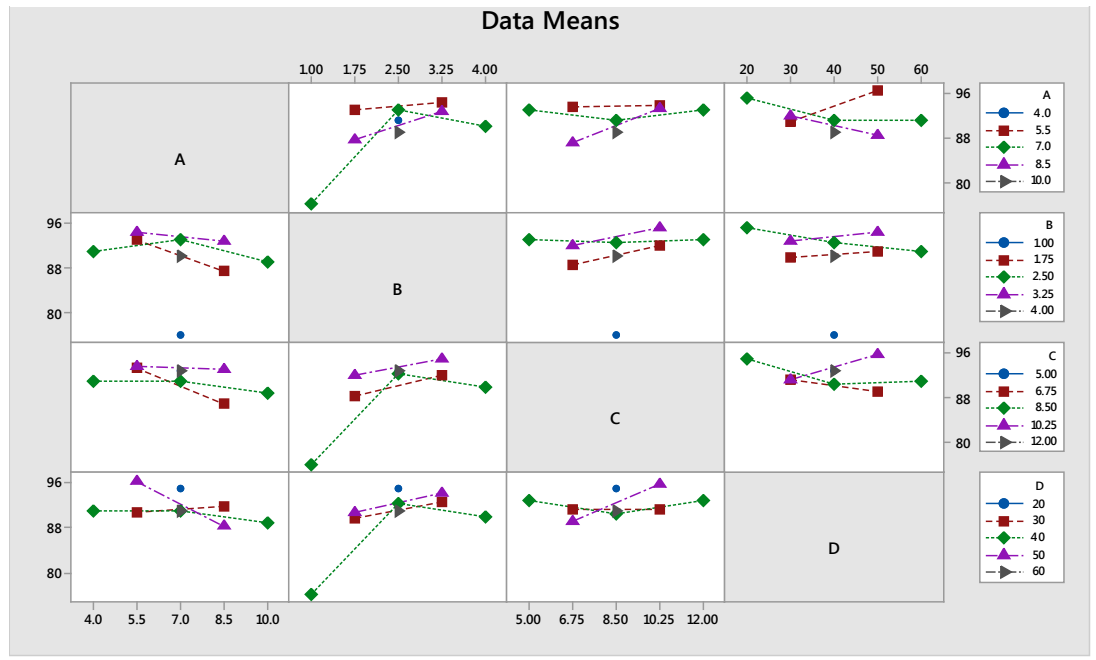

(c)

Figure 8. Full interaction plots. (a) \% color removal of RR223; (b) \%Color removal potency CBBR250; (c) \% COD removal potency. 
Table 7. Kinetic study of dyes decolorization at (T: $23^{\circ} \mathrm{C}, \mathrm{NaCl}: 4 \mathrm{~g} / \mathrm{L}$ and $\mathrm{V}: 12 \mathrm{~V}, \mathrm{pH}=$ $4, \mathrm{I}=1.38$ A. Time $=45 \mathrm{~min}$ ).

\begin{tabular}{ccccccc}
\hline Dye & Kinetic Model & Rate constant & $\begin{array}{c}\mathbf{t}_{1 / 2} \\
(\min )\end{array}$ & $\mathbf{R}^{2}$ & $\begin{array}{c}\text { Energy } \\
\text { Consumption } \\
(\mathbf{k w h})\end{array}$ & Sludge \\
\hline RR 223 & First Order & $4.9 \times 10^{-2} \mathrm{~min}^{-1}$ & 14.14 & 0.597 & $12.42 \times 10^{-3}$ & \\
CBBR250 & Second order & $2.939 \mathrm{M}^{-1} \mathrm{~min}^{-1}$ & 26.17 & 0.767 & $12.42 \times 10^{-3}$ & $1.14 \mathrm{~g} / \mathrm{L}$ \\
\hline
\end{tabular}

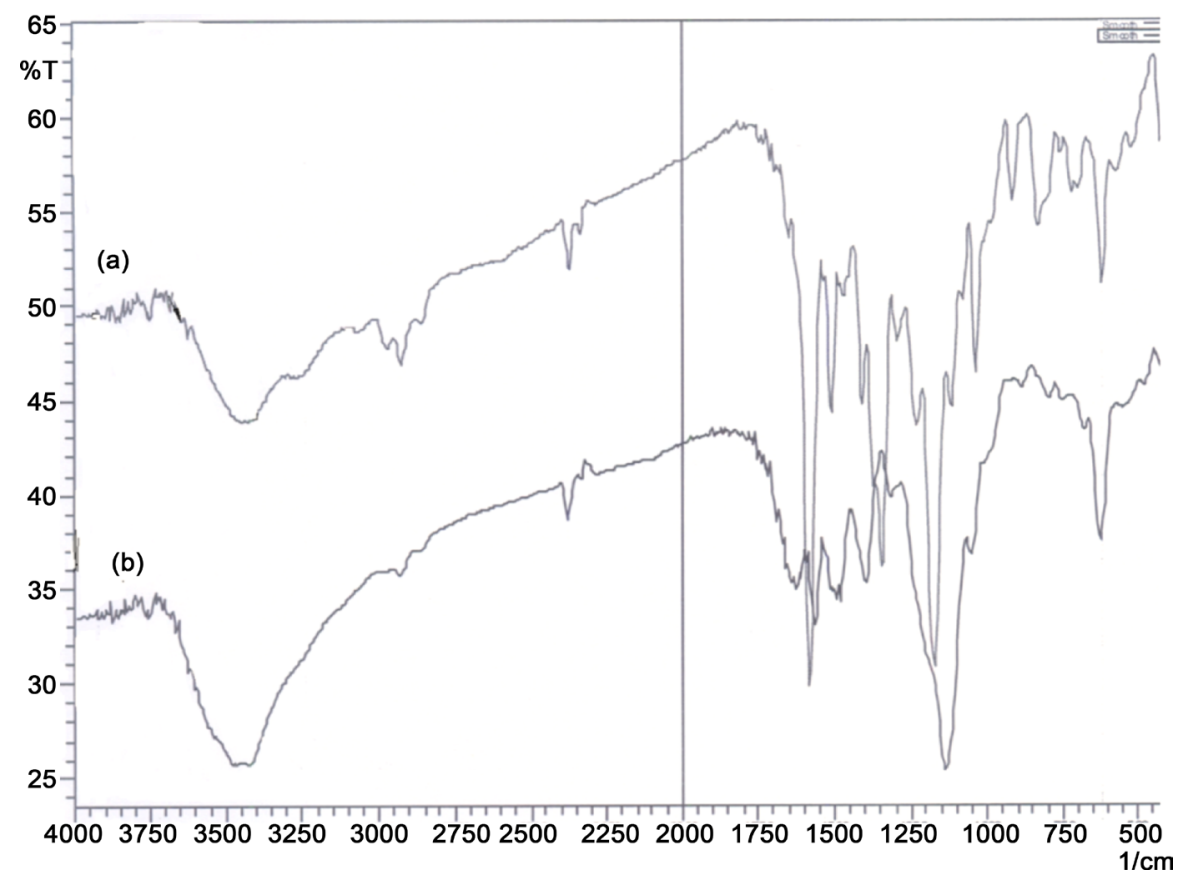

Figure 9. FTIR spectrum of (a) CBBR250 (b) RR223.

was found to be $1.14 \mathrm{~g} / \mathrm{L}$ of the treated wastewater (on a dry substructure). The characterization of the EC-engendered sludge was performed with FT-IR as shown in Figure 9.

\subsection{Influence of the Chemical Structure of the Dyes}

To ascertain the influence of supersession of the dye molecule on EC process efficiency, the decolorization of RR223 and Coomassie brilliant blue was compared. The decolorization of CBBR250 was remotely more rapid in comparison with RR223 at the experimental runs and optimized conditions and both are anionic dyes. These two dyes have different functional groups in chemical structures that influence the reactivity of the molecules in a decolorization process. Due to more soluble nature of RR223 the \% decolorization efficiency was lesser than CBBR250.If a component has more soluble nature than it coagulates gradually. Moreover, CBBR250 has hydrophobic methyl substituent's. Every group like methyl substituent that inclines to decrement the solubility of molecules in water will favor coagulation process. This additionally expounds, at least partly, why decolorization of CBBR250 is scarcely more rapid in comparison with RR223. 


\section{Comparison between This Work and Previous Work}

The comparative work is represented below to show the significance of EC process especially in electrode pair of $\mathrm{Al} / \mathrm{Fe}$ for the treatment of dye effluent discharges. The comparison of electrode combination for different dyes removal is given in Table 8 .

\section{Operating Cost Analysis}

Energy, sacrificial electrodes and chemicals are used during the process and their costs are taken into account in the calculation of the operating cost, as US\$ per $\mathrm{dm}^{3}$ for the treatment of binary dye wastewater. The following equation was used to estimate operating cost.

$$
\text { Operating cost }=a C_{\text {energy }}+b C_{\text {electrode }}+e C_{\text {chemicals }}
$$

where $C_{\text {energy }}, C_{\text {electrode }}, C_{\text {sludge, }}, C_{\text {chemicals }}$, are represented as $a, b, d$, while the $e$ represent the energy intake for every $\mathrm{dm}^{3}$ of wastewater $\left(\mathrm{kWh} / \mathrm{dm}^{3}\right)$. The cost analysis related data is given in Table 9.

\section{Conclusions}

Dyes are extensively utilized in textile industries. They are characterized by water solubility and structural diversity. So, it may be paramount to investigate processes which are able to decolorize wastewaters or to abstract dyes. Many electrochemical processes have been studied, including treatment by EC. The electrochemical process for the abstraction of organic matter from effluent was studied.

Table 8. Electrocoagulation process used for removal of various types of dyes.

\begin{tabular}{|c|c|c|c|c|}
\hline $\begin{array}{c}\text { Reference } \\
\text { no }\end{array}$ & Dye & $\begin{array}{l}\text { Current or } \\
\text { Current density }\end{array}$ & Anode-cathode & $\begin{array}{l}\text { \%Removal } \\
\text { efficiency }\end{array}$ \\
\hline [37] & Reactive orange 84 & $130 \mathrm{~A} / \mathrm{m}^{2}$ & $\mathrm{Fe}-\mathrm{Fe}$ & 66,76 \\
\hline [38] & $\begin{array}{c}\text { Acid red131, Reactive yellow } 86 \text {, Indanthrene blue RS, Basic GR 4, } \\
\text { Reactive yellow } 145\end{array}$ & $0.0625 \mathrm{~A} / \mathrm{cm}^{2}$ & $\mathrm{Al}-\mathrm{Al}$ & 97 \\
\hline [39] & Reactive black B, Orange 3R, Yellow GR & $0.0625 \mathrm{~A} / \mathrm{cm}^{2}$ & $\mathrm{Al}-\mathrm{Al}$ & 98 \\
\hline [40] & Azo, Anthraquinone, Xanthene & $0.3 \mathrm{~A}$ & $\mathrm{Fe}-\mathrm{Fe}$ & 98 \\
\hline [41] & Acid black 52, Acid yellow 220 & $40 \mathrm{~A} / \mathrm{m}^{2}$ & $\mathrm{Al}-\mathrm{Al}$ & 92,95 \\
\hline$[42]$ & Levafix brilliant blue E-B & $100 \mathrm{~A} / \mathrm{cm}^{2}$ & $\mathrm{Al}-\mathrm{Al}, \mathrm{Fe}-\mathrm{Fe}$ & 99,83 \\
\hline [43] & Acid, Reactive & $4.0 \mathrm{~mA} / \mathrm{cm}^{2}$ & Fe-Carbon & 95 \\
\hline [44] & Orange II & $160 \mathrm{~A} / \mathrm{m}^{2}$ & $\mathrm{Al}-\mathrm{Al}$ & 94.5 \\
\hline [45] & Reactive black 5 & $4.575 \mathrm{~mA} / \mathrm{cm}^{2}$ & $\mathrm{Fe}-\mathrm{Fe}$ & 98.8 \\
\hline$[46]$ & Reactive, Basic e & - & $\mathrm{Al}-\mathrm{Al}, \mathrm{Fe}-\mathrm{Fe}$ & $96,85.6$ \\
\hline [47] & Direct red 23 & $30 \mathrm{~A} / \mathrm{m}^{2}$ & $\mathrm{Fe}-\mathrm{Fe}, \mathrm{Al}-\mathrm{Al}$ & $>95$ \\
\hline [48] & Levafix blue CA & $35.5 \mathrm{~mA} / \mathrm{cm}^{2}$ & $\mathrm{Fe}-\mathrm{Fe}$ & 99.5 \\
\hline [49] & Bomaplex red CR-L & $0.50 \mathrm{~mA} / \mathrm{cm}^{2}$ & $\mathrm{Al}-\mathrm{Al}$ & 99.1 \\
\hline This work & RR223, CBBR250 & $1.0 \mathrm{~A}$ & $\mathrm{Al}-\mathrm{Fe}$ & 89,94 \\
\hline
\end{tabular}


Table 9. The cost analysis at optimal conditions ( $\mathrm{Al}$ electrode consumption $=1.488 \times$ $10^{-3} \mathrm{~kg} / \mathrm{dm}^{3}, \mathrm{NaCl}=3 \mathrm{~g} / \mathrm{L}$, dye $=60 \mathrm{mg} / \mathrm{L}$, Reaction time $=60 \mathrm{~min}, \mathrm{pH}=4, \mathrm{~V}=12$ volt $)$.

\begin{tabular}{|c|c|}
\hline Parameter & Quantity \\
\hline Energy consumption $\left(\mathrm{kwh} / \mathrm{dm}^{3}\right)$ & $0.019\left(\mathrm{kwh} / \mathrm{dm}^{3}\right)$ \\
\hline Sodium chloride $\left(\mathrm{kg} / \mathrm{dm}^{3}\right)$ & $0.01 \mathrm{~kg} / \mathrm{dm}^{3}$ \\
\hline sodium Hydroxide consumption $\left(\mathrm{kg} / \mathrm{dm}^{3}\right)$ & $0.01 \mathrm{~kg} / \mathrm{dm}^{3}$ \\
\hline Sludge production $\left(\mathrm{kg} / \mathrm{dm}^{3}\right)$ & $0.7 \mathrm{~kg} / \mathrm{dm}^{3}$ \\
\hline Electrode consumption $\left(\mathrm{Kg} / \mathrm{dm}^{3}\right)$ & $1.488 \times 10^{-3} \mathrm{~kg} / \mathrm{dm}^{3}$ \\
\hline Hydrochloric acid $\left(\mathrm{mL} / \mathrm{dm}^{3}\right)$ & $100\left(\mathrm{~mL} / \mathrm{dm}^{3}\right)$ \\
\hline dyes $\left(\mathrm{Kg} / \mathrm{dm}^{3}\right)$ & $7.5 \times 10^{-4}\left(\mathrm{Kg} / \mathrm{dm}^{3}\right)$ \\
\hline Electrical energy cost $\left(\mathrm{US} \$ / \mathrm{dm}^{3}\right)$ & $3.2734 \times 10^{-4} \mathrm{US} \$ / \mathrm{dm}^{3}$ \\
\hline dye cost $\left(\mathrm{US} \$ / \mathrm{dm}^{3}\right)$ & $0.252 \mathrm{US} \$ / \mathrm{dm}^{3}$ \\
\hline 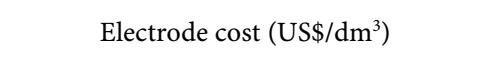 & $0.14 \mathrm{US} \$ / \mathrm{dm}^{3}$ \\
\hline Hydrochloric acid cost(US\$/dm $\left.{ }^{3}\right)$ & $0.1 \mathrm{US} \$ / \mathrm{dm}^{3}$ \\
\hline Hydroxide sodium cost (US\$/dm³ & $1 \mathrm{US} \$ / \mathrm{dm}^{3}$ \\
\hline Sodium chloride $\left(\mathrm{US} \$ / \mathrm{dm}^{3}\right.$ ) & $0.001 \mathrm{US} \$ / \mathrm{m}^{3}$ \\
\hline Potassium dichromate (US $\left.\$ / \mathrm{dm}^{3}\right)$ & $1 \mathrm{US} \$ / \mathrm{dm}^{3}$ \\
\hline Mercury sulphate (US\$/dm³) & $1 \mathrm{US} \$ / \mathrm{dm}^{3}$ \\
\hline Silver sulphate (US\$/dm³) & $1 \mathrm{US} \$ / \mathrm{dm}^{3}$ \\
\hline Total operating cost $\left(\mathrm{US} \$ / \mathrm{dm}^{3}\right)$ & $4.486 \mathrm{US} \$ / \mathrm{dm}^{3}$ \\
\hline
\end{tabular}

This work concerns EC process for textile dyes abstraction of RR223, an azoic dye, and CBBR250 as an anthraquinonic dye. Nevertheless, higher values can be achieved with more sizably voluminous periods of EC process. Most of the aluminium present in the wastewater is removed, and it is the significant advantage of this EC process. Withal, the turbidity associated to organic and inorganic matter was abstracted with the electrocoagulation, making this process ideal for high-polluted wastewater treatment. The amendment of the optical characteristics of the water is fundamental for the prosperity of the EC treatment. Electrocoagulation is an efficient process, even at high $\mathrm{pH}$, for the abstraction of color and total organic carbon in reactive dyes textile wastewater. The amount of electrolyte factor has a more preponderant effect on replication compared to the other factors. High conductivity favors high process performances. According to the results, in acidic medium, $\mathrm{pH}<6, \%$ color and COD abstraction efficiencies are higher in case of aluminum electrode. A $2^{4}$-full factorial CCF design was prosperously employed for experimental design and analysis of results. Analysis of variance showed a high coefficient of correlation value $R^{2}(R R 223)=$ $0.7638, \mathrm{R}^{2}(\mathrm{CBBR} 250)=0.5836$ and $\left.\mathrm{R}^{2}(\mathrm{COD})=0.7927\right)$, thus ascertaining a copacetic adjustment of the second-order regression model with the experimental data. Graphical replication surface and contour plots were habituated to locate the optimum point. Copacetic presage equation was derived for dye 
abstraction utilizing RSM to optimize the parameters. The present study demonstrated the applicability of electrocoagulation method for dye abstraction. Thus, the EC can be considered as a reliable technique for treating wastewater from the textile industry.

\section{Acknowledgements}

The authors acknowledge the financial assistance supported by University of Karachi, Pakistan.

\section{References}

[1] Salazar, R., Brillas, E. and Sirés, I. (2012) Finding the Best $\mathrm{Fe}^{2+} / \mathrm{Cu}^{2+}$ Combination for the Solar Photoelectro-Fenton Treatment of Simulated Wastewater Containing the Industrial Textile Dye Disperse Blue 3. Applied Catalysis B: Environmental, 115, 107-116.

[2] Robinson, T., McMullan, G., Marchant, R. and Nigam, P. (2001) Remediation of Dyes in Textile Effluent: A Critical Review on Current Treatment Technologies with a Proposed Alternative. Bioresource Technology, 77, 247-255.

[3] Martínez-Huitle, C.A. and Brillas, E. (2009) Decontamination of Wastewaters Containing Synthetic Organic Dyes by Electrochemical Methods: A General Review. Applied Catalysis B: Environmental, 87, 105-145.

[4] Brown, D. (1987) Effects of Colorants in the Aquatic Environment. Ecotoxicology and Environmental Safety, 13, 139-147.

[5] Sharma, K.P., Sharma, S., Sharma, S., Singh, P.K., Kumar, S., Grover, R. and Sharma, P.K. (2007) A Comparative Study on Characterization of Textile Wastewaters (Untreated and Treated) Toxicity by Chemical and Biological Tests. Chemosphere, 69, 48-54.

[6] Koch, M., Yediler, A., Lienert, D., Insel, G. and Kettrup, A. (2002) Ozonation of Hydrolyzed Azo Dye Reactive Yellow 84 (CI). Chemosphere, 46, 109-113.

[7] Banat, I.M., Nigam, P., Singh, D. and Marchant, R. (1996) Microbial Decolorization of Textile-Dyecontaining Effluents: A Review. Bioresource Technology, 58, 217-227.

[8] Sahu, O., Mazumdar, B. and Chaudhari, P.K. (2014) Treatment of Wastewater by Electrocoagulation: A Review. Environmental Science and Pollution Research, 21, 2397-2413. https://doi.org/10.1007/s11356-013-2208-6

[9] Murugananthan, M., Raju, G.B. and Prabhakar, S. (2004) Separation of Pollutants from Tannery Effluents by Electro Flotation. Separation and Purification Technology, 40, 69-75.

[10] Can, O.T., Bayramoglu, M. and Kobya, M. (2003) Decolorization of Reactive Dye Solutions by Electrocoagulation using Aluminum Electrodes. Industrial \& Engineering Chemistry Research, 42, 3391-3396. https://doi.org/10.1021/ie020951g

[11] Kumar, M., Ponselvan, F.I.A., Malviya, J.R., Srivastava, V.C. and Mall, I.D. (2009) Treatment of Bio-Digester Effluent by Electrocoagulation using Iron Electrodes. Journal of Hazardous Materials, 165, 345-352.

[12] Chen, G. (2004) Electrochemical Technologies in Wastewater Treatment. Separation and Purification Technology, 38, 11-41.

[13] Pajootan, E., Arami, M. and Mahmoodi, N.M. (2012) Binary System Dye Removal by Electrocoagulation from Synthetic and Real Colored Wastewaters. Journal of the Taiwan Institute of Chemical Engineers, 43, 282-290. 
[14] Youchun, Z., Dunwen, L., Yongqi, Z., Jianmin, L. and Meiqiang, L. (1991) The Study of the Electrolysis Coagulation Process using Insoluble Anodes for Treatment of Printing and Dyeing Wastewater. Water Treatment, 6, 227-236.

[15] Cruz-González, K., Torres-Lopez, O., García-León, A.M., Brillas, E., Hernández-Ramírez, A. and Peralta-Hernández, J.M. (2012) Optimization of Electro-Fenton/BDD Process for Decolorization of a Model Azo Dye Wastewater by Means of Response Surface Methodology. Desalination, 286, 63-68.

[16] APHA (1992) Standard Methods for Examination of Water and Wastewater. American Water Work Association, New York.

[17] Yu, P. and Chao, X. (2013) Statistics-Based Optimization of the Extraction Process of Kelp Polysaccharide and Its Activities. Carbohydrate Polymers, 91, 356-362.

[18] Ravikumar, K., Pakshirajan, K., Swaminathan, T. and Balu, K. (2005) Optimization of Batch Process Parameters using Response Surface Methodology for Dye Removal by a Novel Adsorbent. Chemical Engineering Journal, 105, 131-138.

[19] Kobya, M., Demirbas, E. and Sahin, O. (2012) Effect of Operational Parameters on the Removal of Phenol from Aqueous Solutions by Electrocoagulation using Fe and Al Electrodes. Desalination and Water Treatment, 46, 366-374. https://doi.org/10.1080/19443994.2012.677565

[20] Do, J.S. and Chen, M.L. (1994) Decolourization of Dye-Containing Solutions by Electrocoagulation. Journal of Applied Electrochemistry, 24, 785-790. https://doi.org/10.1007/BF00578095

[21] Ghernaout, D., Mariche, A., Ghernaout, B. and Kellil, A. (2010) Electromagnetic Treatment-Doubled Electrocoagulation of Humic Acid in Continuous Mode using Response Surface Method for Its Optimisation and Application on Two Surface Waters. Desalination and Water Treatment, 22, 311-329. https://doi.org/10.5004/dwt.2010.1120

[22] Ghernaout, B., Ghernaout, D. and Saiba, A. (2010) Algae and Cyanotoxins Removal by Coagulation/Flocculation: A Review. Desalination and Water Treatment, 20, 133-143. https://doi.org/10.5004/dwt.2010.1202

[23] Daneshvar, N., Khataee, A.R., Ghadim, A.A. and Rasoulifard, M.H. (2007) Decolorization of CI Acid Yellow 23 Solution by Electrocoagulation Process: Investigation of Operational Parameters and Evaluation of Specific Electrical Energy Consumption (SEEC). Journal of Hazardous Materials, 148, 566-572.

[24] Mouedhen, G., Feki, M., Wery, M.D.P. and Ayedi, H.F. (2008) Behavior of Aluminum Electrodes in Electrocoagulation Process. Journal of Hazardous Materials, 150, 124-135.

[25] Kumar, V. (2017) A Review on the Feasibility of Electrolytic Treatment of Wastewater: Prospective and Constraints. Constraints, 2, 52-62.

[26] Attour, A., Touati, M., Tlili, M., Amor, M.B., Lapicque, F. and Leclerc, J.P. (2014) Influence of Operating Parameters on Phosphate Removal from Water by Electrocoagulation using Aluminum Electrodes. Separation and Purification Technology, 123, 124-129.

[27] İrdemez, Ş., Demircioğlu, N., Yıldız, Y.Ş. and Bingül, Z. (2006) The Effects of Current Density and Phosphate Concentration on Phosphate Removal from Wastewater by Electrocoagulation using Aluminum and Iron Plate Electrodes. Separation and Purification Technology, 52, 218-223.

[28] Vlyssides, A.G., Karlis, P.K. and Zorpas, A.A. (1999) Electrochemical Oxidation of Noncyanide Strippers Wastes. Environment International, 25, 663-670. 
[29] Comninellis, C. (1994) Electrocatalysis in the Electrochemical Conversion/Combustion of Organic Pollutants for Waste Water Treatment. Electrochimica Acta, 39, 1857-1862.

[30] Wang, Y.Q., Gu, B. and Xu, W.L. (2009) Electro-Catalytic Degradation of Phenol on Several Metal-Oxide Anodes. Journal of Hazardous Materials, 162, 1159-1164.

[31] Moreno, H.A., Cocke, D.L., Gomes, J.J.A., Morkovsky, P., Peterson, E. and Parga, J.R. (2006) Electrocoagulation: COD Removal Mechanism. The 2006 Annual Meeting.

[32] Hu, Z., Chandran, K., Smets, B.F. and Grasso, D. (2002) Evaluation of a Rapid Physical-Chemical Method for the Determination of Extant Soluble COD. Water Research, 36, 617-624.

[33] Jadhav, S.B., Chougule, A.S., Shah, D.P., Pereira, C.S. and Jadhav, J.P. (2015) Application of Response Surface Methodology for the Optimization of Textile Effluent Biodecolorization and Its Toxicity Perspectives using Plant Toxicity, Plasmid Nicking Assays. Clean Technologies and Environmental Policy, 17, 709-720. https://doi.org/10.1007/s10098-014-0827-3

[34] Gönder, Z.B., Kaya, Y., Vergili, I. and Barlas, H. (2010) Optimization of Filtration Conditions for CIP Wastewater Treatment by Nanofiltration Process using Taguchi Approach. Separation and Purification Technology, 70, 265-273.

[35] Kasiri, M.B., Aleboyeh, H. and Aleboyeh, A. (2008) Modeling and Optimization of Heterogeneous Photo-Fenton Process with Response Surface Methodology and Artificial Neural Networks. Environmental Science \& Technology, 42, 7970-7975. https://doi.org/10.1021/es801372q

[36] Aisyah, S.I., Norfariha, M.S., Azlan, M.M. and Norli, I. (2014) Comparison of Synthetic and Natural Organic Polymers as Flocculant for Textile Wastewater Treatment. Iranica Journal of Energy \& Environment, 5, 436-445.

[37] Abu Hassan, M.A., Pei, L. and Noor, Z.Z. (2004) Coagulation and Flocculation Treatment of Wastewater in Chicken Processing Industry Using Chitosan. Journal of Chemical and Natural Resources Engineering, 4, 43-53.

[38] Khandegar, V. and Saroha, A.K. (2013) Electrochemical Treatment of Effluent from Small-Scale Dyeing Unit. Indian Chemical Engineer, 55, 112-120. https://doi.org/10.1080/00194506.2013.798889

[39] Khandegar, V. and Saroha, A.K. (2013) Electrochemical Treatment of Textile Effluent Containing Acid Red 131 Dye. Journal of Hazardous, Toxic, and Radioactive Waste, 18, 38-44. https://doi.org/10.1061/(ASCE)HZ.2153-5515.0000194

[40] Wei, M.C., Wang, K.S., Huang, C.L., Chiang, C.W., Chang, T.J., Lee, S.S. and Chang, S.H. (2012) Improvement of Textile Dye Removal by Electrocoagulation with Low-Cost Steel Wool Cathode Reactor. Chemical Engineering Journal, 192, 37-44.

[41] Zodi, S., Merzouk, B., Potier, O., Lapicque, F. and Leclerc, J.P. (2013) Direct Red 81 Dye Removal by a Continuous Flow Electrocoagulation/Flotation Reactor. Separation and Purification Technology, 108, 215-222.

[42] Akbal, F. and Kuleyin, A. (2011) Decolorization of Levafix Brilliant Blue E-B by Electrocoagulation Method. Environmental Progress \& Sustainable Energy, 30, 29-36. https://doi.org/10.1002/ep.10437

[43] Körbahti, B.K. and Tanyolaç, A. (2008) Electrochemical Treatment of Simulated Textile Wastewater with Industrial Components and Levafix Blue CA Reactive Dye: Optimization through Response Surface Methodology. Journal of Hazardous Mate- 
rials, 151, 422-431.

[44] Mollah, M.Y.A., Gomes, J.A., Das, K.K. and Cocke, D.L. (2010) Electrochemical Treatment of Orange II Dye Solution-Use of Aluminum Sacrificial Electrodes and Floc Characterization. Journal of Hazardous Materials, 174, 851-858.

[45] Şengil, İ.A. and Özacar, M. (2009) The Decolorization of CI Reactive Black 5 in Aqueous Solution by Electrocoagulation using Sacrificial Iron Electrodes. Journal of Hazardous Materials, 161, 1369-1376.

[46] Charoenlarp, K. and Choyphan, W. (2009) Reuse of Dye Wastewater through Colour Removal with Electrocoagulation Process. Asian Journal on Energy and Environment, 10, 250-260.

[47] Phalakornkule, C., Polgumhang, S. and Tongdaung, W. (2009) Performance of an Electrocoagulation Process in Treating Direct Dye: Batch and Continuous Upflow Processes. World Academy of Science, Engineering and Technology, 57, 277-282.

[48] Aleboyeh, A., Daneshvar, N. and Kasiri, M.B. (2008) Optimization of CI Acid Red 14 Azo Dye Removal by Electrocoagulation Batch Process with Response Surface Methodology. Chemical Engineering and Processing. Process Intensification, 47, 827-832.

[49] Yildiz, Y.Ş. (2008) Optimization of Bomaplex Red CR-L Dye Removal from Aqueous Solution by Electrocoagulation using Aluminum Electrodes. Journal of Hazardous Materials, 153, 194-200.

\section{Submit or recommend next manuscript to SCIRP and we will provide best} service for you:

Accepting pre-submission inquiries through Email, Facebook, LinkedIn, Twitter, etc. A wide selection of journals (inclusive of 9 subjects, more than 200 journals)

Providing 24-hour high-quality service

User-friendly online submission system

Fair and swift peer-review system

Efficient typesetting and proofreading procedure

Display of the result of downloads and visits, as well as the number of cited articles

Maximum dissemination of your research work

Submit your manuscript at: http://papersubmission.scirp.org/

Or contact ojapps@scirp.org 